European Journal of Archaeology 24 (4) 2021, 519-555

This is an Open Access article, distributed under the terms of the Creative Commons Attribution-

NonCommercial-NoDerivatives licence (http://creativecommons.org/licenses/by-nc-nd/4.0/), which permits non-commercial re-use, distribution, and reproduction in any medium, provided the original work is unaltered and is properly cited. The written permission of Cambridge University Press must be obtained for commercial reuse or in order to create a derivative work.

\title{
Forum: Populism, Identity Politics, and the Archaeology of Europe
}

Daniela Hofmann ${ }^{1}$ (D), Emily Hanscam $^{2}$, Martin Furholt $^{3}$, Martin Bača $^{4}$, Samantha S. Reiter ${ }^{5}$, Alessandro Vanzetti ${ }^{6}$, Kostas Kotsakis ${ }^{7}$, Håkan Petersson ${ }^{8}$, Elisabeth Niklasson ${ }^{9}$, Herdis Hølleland ${ }^{10}$ (i) and Catherine J. Frieman ${ }^{11}$ (iD

${ }^{1}$ Department of Archaeology, History, Culture Studies and Religion, University of Bergen, Norway

${ }^{2}$ Amsterdam Centre for Ancient Studies and Archaeology, University of Amsterdam, The Netherlands

${ }^{3}$ Department of Archaeology, Conservation and History, University of Oslo, Norway

${ }^{4}$ Department of Archaeology, Comenius University in Bratislava, Slovakia

${ }^{5}$ Department of Environmental Archaeology and Materials Science, The National

Museum of Denmark, Brede, Denmark

${ }^{6}$ Department of Ancient World Studies, Sapienza University of Rome, Italy

${ }^{7}$ Department of Archaeology, Aristotle University of Thessaloniki, Greece

${ }^{8}$ Sydsvensk Arkeologi AB, Kristianstad, Sweden

${ }^{9}$ Department of Archaeology, University of Aberdeen, UK

${ }^{10}$ Department of Heritage and Society, Norwegian Institute for Cultural Heritage Research, Oslo, Norway

${ }^{11}$ School of Archaeology and Antbropology, Australian National University, Canberra, Australia

\section{InTroduction: ArchaEOlOGY AND Populism}

\section{Daniela Hofmann and Catherine} J. Frieman

The kind of liberal and open-minded society on which most academics rely to freely conduct their research is increasingly under threat, even within democratic societies of long standing. The past is by no means neutral in this, whether this be the then American president threatening to attack the antiquities of Iran in early 2020 (a war crime if carried out), or a right-ofcentre UK politician using a prehistoric henge monument to argue that Britain's future should lie outside the European Union (Brophy, 2019). These kinds of developments are generally described as 'populist', a term that refers to the simplification of complex problems and appeals to broad sectors of the population. Here, we follow Müller (2016: 3-4) in arguing that 'populism' also implies exclusionary and polarizing identity politics in which difference and dissent are treated as moral failings rather than questions for compromise. 
This frequently includes an element of anti-elitism. Such a discourse has often (though not universally) been associated with the right of the political spectrum, and many authors in this contribution thus begin by tracing its roots in nationalism (e.g. Martin Furholt) or directly addressing national populism (e.g. Elisabeth Niklasson and Herdis Hølleland). However, as Martin Bača reminds us, this is not the only populist strand there is, and we have not imposed an overall definition on our authors. Their arguments will also be applicable to other situations.

Yet, while simplistic election promises sound convincing to increasing numbers of people at both ends of the political spectrum, there is also a growing market for popular histories, including internationally chart-topping works by Yuval Noah Harari (e.g. Harari, 2015) and others. Books on archaeological topics can also reach a wide audience, with, for example, volumes on the Nebra Sky Disc and on archaeogenetics ending up on the German Der Spiegels non-fiction bestseller list in 2019 (Meller \& Michel, 2018; Krause \& Trappe, 2019). In addition, social media allow us (and other interpreters of the past) to reach ever greater numbers of people.

The majority of the texts collected here were first presented at a session of the European Association of Archaeologists' conference in Bern in 2019, which attempted to address this dual development as it has gathered pace over the last decade. While political engagement in archaeology is nothing new - and amongst others includes a long history of feminist scholarship (e.g. Conkey, 2002), strategies for democratization (e.g. recently Milek, 2018; Nilsson Stutz, 2018), and calls for a greater relevance of archaeology in environmental and social debates (e.g. Kiddey, 2017; Kohler \& Rockman, 2020)-here we are particularly concerned with the very current problem of an ever more vocal and pervasive populist debate that threatens the discursive foundations on which rational argument is possible. How should we respond? How can we deal with the sometimes uncomfortable limelight that is increasingly being trained on our discipline? What can be done when the public's expectations, or the use of the past by various actors, run counter to our own convictions (and/or what can be reasonably inferred from the available data)?

There are no easy answers to these questions, but our authors go some way towards demonstrating the variety of the problem across different archaeological fields and in various European regions. While this is first and foremost a call for greater engagement and debate across the discipline, we would argue that a concerted response to such developments entails a two-pronged approach that begins both at a high level of generality and at the level of daily working routines.

\section{The banality of evil}

Taking their cue from Hannah Arendt's (1963) famous analysis of the 1962 Eichmann trial, several contributors (most directly Martin Furholt and Emily Hanscam) point out that the basic tools of archaeological classification and interpretation already come with methodological baggage. Foremost among them is the culture concept, widely critiqued in a variety of research traditions (e.g. Binford, 1962; Clarke, 1968; Wotzka, 2000) but astonishingly persistent in large swathes of Europe. Using 'culture' as a foundational concept is always in danger of succumbing to methodological nationalism (Wimmer \& Glick Schiller, 2003) since the concept assumes the homogeneity and internal unity of the entity under study and stresses its separation from others. Yet 'cultures' are the basic chronological building blocks 
of prehistory in many countries (Roberts \& Vander Linden, 2011; Ivanovaite et al., 2020). Radiocarbon dating, an obvious alternative, is sometimes explicitly mistrusted, and typological systems seen as providing greater chronological precision. In a self-perpetuating spiral, this means that few good-quality ${ }^{14} \mathrm{C}$ dates are available to build secure absolute chronologies (the allegedly well-studied Linearbandkeramik is a case in point, as the protracted exchange among Jakucs et al., 2016; Bánffy et al., 2018; Strien, 2017, 2019 illustrates), effectively forcing researchers to continue using 'culture' designations, with all attendant problems intact.

Recent aDNA studies have been criticized for perpetuating and biologizing this unsatisfactory model through the use of 'culture' names to refer to groups of samples (Frieman \& Hofmann, 2019; for first steps towards a solution, see Eisenmann et al., 2018). Again, this hides diversity, both in the past and in the use of modern-day reference populations which, depending on the aim of the original study from which they are derived, can often lump very large and heterogeneous national groups (e.g. 'the French') into a single dot on a graph. This 'geneticization of notions of citizenship and belonging' (Pálsson, 2007: 113), as well as erroneous ideas of 'isolated' indigenous populations (Pálsson, 2007: 157), is widespread, for instance in the creation of databases for medical purposes, and is now also being uncritically imported into past settings, where it compounds our own methodological weaknesses.

Even where 'culture' names have largely disappeared from use, problems remain, for instance in the way archaeological entities are often represented on static maps with clear boundaries (critiqued e.g. in Anderson-Whymark \& Garrow, 2015). Amongst other problems, these clearly bounded coloured blobs, occasionally connected by arrows, immediately convey a raft of unconsidered assumptions, such as the idea that the movement of people in the past involved large groups moving once from a clearly defined origin to a determined end point (see discussion in Wiedemann, 2017: 145). Such convenient visual simplifications hide the complexity and diversity of the underlying processes, but play to our present perceptions of, for example, migration. Technologies for making more dynamic maps exist; but, in many cases, it remains difficult to find and encode location data, or to deal with often coarsely dated sites spread across databases in multiple countries using incompatible recording systems. Such very basic structural problems are serious challenges to Big Data or synthetic approaches, and there are no quick fixes.

Similarly, Panich and Schneider (2019) detail some of the challenges they encountered in trying to document Native American post-1492 persistence in parts of California when there is no consistent way in which this can be recorded in heritage management databases. The resulting casual erasure of Native American voices continues to affect heritage decisions and the presentation of Indigenous history to a wider public. Reversing this trend requires the large-scale modification of databases and the re-entry of records, as well as a substantial financial commitment to using absolute dating methods. In a European setting, and with multiple nations involved, this kind of project would not come easy. It is expensive, but not the kind of glamorous research that attracts substantial funding. Yet, if we want to finally leave behind conventions that are deeply rooted in the nationalist past of our discipline and create standards and protocols fit for addressing new kinds of questions, we must begin with the inherent biases of our everyday working tools. 


\section{Bright new futures}

At the opposite end of the scale is the question of what kinds of ideas or narratives we can offer our varied publics, and whether simply telling them, as opposed to involving stakeholders throughout the research process, is even enough (see debate in Thomas, 2015; and here particularly Samantha Reiter and Kostas Kotsakis). Contributors to this forum have addressed this from many angles, but there are many more to be covered; the contributions to this volume represent neither every corner of Europe, nor all experiences of European populism.

First is the pervasive idea, evident across many contexts, that heritage sites are primarily about presenting the identity and continuity of a closed group, however defined (e.g. national/ethnic origin, professional, gendered, religious, etc.), rather than envisaged as spaces for dialogue and encounter more generally (see e.g. contributions in Holtorf et al., 2019). This is explored here by Herdis Hølleland and Elisabeth Niklasson, Håkan Petersson, and Alessandro Vanzetti.

Heritage practitioners have long argued for non-static and diverse notions of a heritage that is above all engaged in generating a future (e.g. Holtorf \& Högberg, 2015). Many examples of good practice already exist (e.g. Synnestvedt, 2009; Perry, 2019), but the next step is a concerted pan-European effort to lastingly change the agendas of national heritage bodies and funders, and to challenge some of our publics into broadening their ideas about what 'heritage' can be. Emily Hanscam, Martin Furholt, Samantha Reiter, Martin Bača, and Kostas Kotsakis variously offer critique and solutions along these lines.

As one contributor to the original session discussion pointed out, archaeologists are very good at knowing what they do not want, but much worse at deciding what they want instead. Indeed, when reacting to populism there is more than one valid strategy, as the contributors to this forum show. But all agree that more communication is central. Although archaeologists such as Gordon Childe and Mortimer Wheeler were once part of more or less explicitly political but very vibrant public debates about history, civilization, and culture (see e.g. Moshenska \& Zuanni, 2018; Thornton, 2018), today relatively few of us direct our work at popular audiences. Of those who do, many are professional television presenters rather than active researchers, or they are (frequently early career) academics active in science communication on social media (e.g. the excellent work on Twitter by Flint Dibble (@FlintDibble), Sarah Parcack (@indyfromspace), and Kristina Killgrove (@DrKillgrove) among many others) and a huge variety of international blogs and online initiatives, some run by archaeology students (such as https://anarchaeologie.de/ or https://www.miss-jones. de/). Nevertheless, this is manifestly not enough to shift wider public discourses regarding issues such as a personal connection to the distant past or the biologization of identity.

We would argue that changing the routines of our daily practice and finding the courage to leap into wider social debates are unavoidable, and that our discipline will be harmed if we put this off any longer. There is an obvious role here for international organizations like the EAA, particularly because wider structural change is required. University reward systems and the demands of many archaeological jobs across Europe actively discourage spending time on communicating with the public, which competes with writing the academic papers needed for promotion and is not rewarded by the coveted 'publication points' which are the 
basis for resource allocation in many departments. Similarly, heritage bodies and museums operate within governmental funding structures and constraints, meaning that even carefully considered outreach and education initiatives can fall prey to local politics or perceptions of economic need (discussed here, amongst others, by Håkan Peterssen and Alessandro Vanzetti). While there are steps we can take as individuals, expecting single scholars and heritage professionals to constantly redress much larger imbalances in resource allocation and power structures is not a viable strategy. From campaigning for more media training and more concerted institutional support in dealing with any resulting controversy, to demanding structural recognition for outreach work and forcing critical reflection on the impact of open access policies on different university departments, there is a mountain to climb.

The pieces collected here are intended as a call to arms for further reflection on the problems facing us right now, as well as offering initial suggestions for solutions. They are loosely arranged from those with a more reflexive focus on archaeological concepts and on biases within and outside the discipline to those tracing specific problems (and reactions) in concrete situations, although there is of course plenty of overlap. We hope that together they will stimulate thought and action.

\section{The Postnational Critique - A Response to Reactionary Populism? Emily Hanscam}

\section{Introduction}

The entanglement between archaeology and politics is old news, but the sheer pervasiveness of this relationship and its long- term global impact is becoming increasingly apparent. It is evident that research about the past has great potential to influence the present; not only can our work as archaeologists directly reinforce contemporary structural inequalities such as gender, race, and class but, once we produce knowledge about the past, it can and will be used by anyone, in support of a range of political agendas (Bonacchi et al., 2018; Brophy, 2018). The relationship between archaeology and the contemporary world must not be understood as a matter of the degree to which research is affected by politics, despite the ease of remaining inside a dualistic perspective that views research on the past as 'biased' or 'objective', 'right' or 'wrong'. The reality is that all research concerning the past is influenced by politics and contemporary perspectives.

Our world has seen rapid change over the past few years, caused by the swift rise of nationalism and reactionary populism, which has proven itself capable of winning political power, frequently appealing to an idealized view of the past: Trump won the American presidency with the slogan 'Make America Great Again'. As of late 2020, the political tide in the United States has shifted towards rejecting Trumpism, but it is likely that the nativist movement he inspired, and the white supremacy he legitimized, will haunt the US long into the future. Archaeology is, therefore, becoming even more relevant for questions of identity than ever before. And, as Gardner (2018: 1) points out, this is a good thing: it gives us the ability to weigh in on public debates regarding the use of the past to inform modern identities.

The problem is that strict categories of identity like nationality, religion, class, gender, and ethnicity have become entrenched; Appiah (2018: xvi) calls them the 'lies that bind'. They are valuable and powerful because they allow people to 
accomplish things together as groups, but it is crucial to remember that all these categories were invented (Appiah, 2018). This does not change the fact that the experience of social belonging is powerful and leads to actions causing imagined origin[s] [to] be translated into social reality very quickly' (Sommer, 2011: 173). Nevertheless, we need to be persistent in exposing flaws in our thinking that lend national and nativist narratives legitimacy. Here, methodological nationalism, i.e. the idea that 'national identification is a fundamental aspect of human nature' (Vasilev, 2019: 3) is key. The nation is popularly seen as one of the most preeminent forms of collective humanity. And yet, the nation was never intended to be 'the final' solution (Cannadine, 2013: 87); the nation is neither inevitable, nor 'natural'.

The idea of one ethnic group with a shared language, religion, ancestry, and culture occupying a specific territory has colonized thinking so effectively that the nation is both accepted as the 'default' mode of human organization and projected back into history. In reality, homogeneous national identities occupying exclusive national spaces are non-existent. Yet they persist in the popular imagination, in part because of the power of national myths. The nation-state as a political body is volatile and problematic, but nationalism itself is imbued with a sense of timelessness, giving it jurisdiction over interpretations of the past (Cinpoeş, 2010: 18). We are, therefore, left with the sense that human societies are destined to be segregated into different nation-states.

This leaves archaeologists, and other scholars of the past, with a choice: once we recognize the continued power of nationalism over history and over contemporary identities, do we attempt to minimize its impact on our work, or do we explicitly engage with the politics of the past?

\section{Political engagement in archaeology}

Global politics have undergone a dramatic transformation in the past few years, and a number of archaeologists have recently been calling, myself included (Hanscam, 2019), for a more politically engaged archaeology (Brophy, 2018; Gardner, 2018; González-Ruibal et al., 2018; Popa, 2019; Kiddey, 2020). Given the current climate of resurging reactionary populism and far-right nationalism, it is vital that archaeologists, as producers of knowledge about the past, take an active stand against its political misuse. As crisis after crisis unfolds, the voices calling for a more explicit engagement with the political side of archaeology are growing louder.

Is this current the result of a long-term trend or does the movement in favour of a politically engaged archaeology represent more of a watershed moment? It certainly appears to be gaining traction, but it was also rejected only a few years ago, in an article originating from a group discussion panel at the 2015 European Archaeological Association annual meeting in Glasgow. In the forum article 'What is 'European archaeology'? What should it be?' Babic and Robb warn against political alignment, stating that '[for archaeologists] to build an emotive commitment to European identity is a bad idea' (Babić et al., 2017: 6). It may be that those who rejected a politically engaged archaeology in 2017 still do today, and it may be that those who are now calling for archaeologists to become political actors have long held these views. Kristiansen (2008), for example, has been arguing for years that archaeologists should explicitly build a narrative for Europe.

The point I wish to highlight here is that in five short years (2015 to 2020), the idea of a politically unengaged archaeology has become untenable. It used to be a question that inspired rousing discussion - I was in the audience of the 2015 group 
discussion panel at the EAAs that inspired Babić and colleagues (2017), and I remember being impressed by the variety of opinions represented, and the strength of the conviction behind many. Now that we are all painfully aware of how quickly geopolitical climates can shift, I believe the discussion should change from 'should we?' to 'how best can we become political actors?'. The latter question is not easily answered, but I think that an essential first step involves questioning the assumptions we continue to make because of the power of methodological nationalism.

\section{The postnational critique}

The postnational critique can help us question our assumptions. The theory of postnationalism, first developed in the early 2000s, was initially linked to globalization because scholars believed that a postnational, or completely globalized, world was inevitable (Özkirimli, 2005). Some argued the world was in a postnational state in the late 1990s or early 2000s, with the move towards multinational bodies like the European Union (Habermas, 2001). The theory of postnationalism also acted as a tool to critique nationalism (Appadurai, 1996: 158), linked to theories of hybridity and new ways of understanding relationships (Sutherland, 2012: 45). My use of postnationalism aligns most closely with these two critical definitions because I do not see postnationalism as inevitable. Postnationalism is used here as a means of disrupting 'natural' assumptions about the status of nations and national identity.

The postnational critique is one potential way forward for political engagement in archaeology. It encourages us to overturn assumptions owed to the influence of nationalism, to examine how our view of the past is constrained in particular contexts, and to contemplate how that past might, nonetheless, have the potential to advocate for more inclusive understandings of human relationships and identities. Methodological nationalism remains embedded within archaeological research because it is not explicitly denied. Meanwhile, archaeology has rightfully hesitated to create authoritative narratives since this can perpetuate the power imbalances critiqued by postcolonialism. Like postcolonialism, the postnational critique aims to dismantle power structures, but we must consider that nationalism has grown in power in part because of aspects of postcolonialism. For the past few decades, multivocality, or allowing multiple voices to come through, has been a popular means of addressing this imbalance. Yet multivocality does not allow us to combat the alternative narratives of extremist groups, such as those on the far right, which have become increasingly influential since 2016 (González-Ruibal, 2018a). We must find a way to combat these narratives, since, as we have discovered with the Brexit process and the Trump presidency, allowing them to remain unopposed has consequences which were unimaginable only a few years ago. Furthermore, rightwing accounts in particular draw on archaeological sources of information to construct their narratives (Bonacchi et al., 2018; Hingley et al., 2018); from a certain perspective, it is our responsibility to provide an alternative.

The postnational critique involves two steps: first, to understand how nationalism is created and sustained in a particular context and, second, to study the past to identify what themes emerge through the application of a postnational lens. The postnational critique is also a vision; it is a vision of how our understanding of categories of difference (identities) might change, if we can critique the assumptions on which they were built. It is also a 
reminder that we cannot allow movements such as far-right nationalism or reactionary populism to drown out our voices and authority, especially if we can demonstrate, clearly and persistently, that these narratives are built on false assumptions about the past.

Postnational themes, therefore, vary depending on the context. In Romania, for example, a key theme is to recognize the long-term impact of migration on the landscape of south-eastern Europe. Present-day Romania consists of a territory that has served as the crossroads between Europe, Asia, and the Near East since the Palaeolithic, with sustained periods of movement like the 'Age of Migrations' in Late Antiquity and the early medieval period. The fact that the Romanian national narrative has persistently emphasized an autochthonous population (a population allegedly originating in the Iron Age with the Romans and Dacians) has fostered a national narrative that recognizes the diversity of encounters and the peoples present but does not allow for their agency in the foundation of the Romanian nation. This narrative is heavily entangled with Romanian archaeology (Popa, 2015; Popa \& Hanscam, 2019-2020).

Through the postnational critique, we can shift from a territorial definition of the past to one of connection: we can highlight the encounters taking place, for example, in the region of modern Romania, rather than contrasting migratory peoples against the survival of the 'autochthonous' population. Viewing the past in terms of connections is not the only way to understand history, nor is it argued to be the 'correct' way; rather, it demonstrates that we must recognize the undue influence nationalism continues to have on our understanding of history. It is also vital that we critique the projection of modern national borders backwards into the past, and the subsequent use of this nationally bounded past to legitimize the present. In emphasizing the absence of a restrictive overarching paradigm through which history is understood, the postnational critique allows us to highlight the numerous encounters and negotiations between people, thereby showing the infinite possibilities the past contains.

In recognition of the consequences of inaction, let us use approaches like the postnational critique which help us in the age of the Anthropocene to 'rearm to face a capitalism that no longer requires scientific legitimacy' (González-Ruibal, 2018a). Let us become political actors, engage with the politics of the past, and build a more inclusive future.

\section{Ethnic Essentialism, Clash of Cultures, Biologization of Identities: How Flawed ConcePts Affect the Archaeogenetics Discourse Martin Furholt}

Perhaps due to the fascination of the powerful, cutting-edge technology and sophisticated modelling applied in ancient DNA (aDNA) studies, there seems to be a widespread misconception that the information provided by molecular biology should be objective, inherently unbiased, and trustworthy, i.e. 'hard' scientific facts as opposed to the ideological, potentially biased interpretative frameworks of the social sciences (Frieman \& Hofmann, 2019). Yet, scientific categories are socially constructed and thus subject to the influence of socio-economic interests, ideological agendas, and cultural preferences. While there is no doubt that DNA analyses are measuring real phenomena, at every step of the analytical process, and especially so when creating units of analysis and using those units to reconstruct past human conduct, we are clearly within the field of premises and culturally 
determined preferences. Unfortunately, in the context of the breakthrough of archaeogenetic methodologies in the last decade (Allentoft et al., 2015; Haak et al., 2015; Olalde et al., 2018, 2019), too little effort was put into scrutinizing the categories applied in modelling prehistoric social processes. In fact, the most outdated and flawed concepts of social group organization and migration, dating back to the early days of culture historical archaeology, were chosen. The idea of 'archaeological cultures', representing closed and static groups as well as distinct biological populations, and the corresponding idea of collective mass migration as the main driver of change, has long been debunked. For third-millennium BC Europe, the result was the simplified narrative of 'the Yamnaya people' (represented by the 'Yamnaya culture') 'migrating' from the Eastern European steppes westwards, there creating the 'Corded Ware people' and later the 'Beaker folk' (represented by Corded Ware and Bell Beaker 'cultures').

The archaeological culture is not a neutral tool to classify archaeological material, but a version of an anthropological concept stemming from a colonial and culturally narrow mindset (Tylor, 1871), later adopted by archaeology; it is based on a specific view of human nature and sociality permeated by right-wing ideologues in a nationalist, chauvinist, and racist Zeitgeist during the late nineteenth and early twentieth centuries. Its leading proponent, Gustaf Kossinna (who wrote on the origins of the Germans in 1911), famously saw prehistoric archaeology as an 'outstandingly national science' (the subtitle of his 1912 work) (Veit, 1989; Trigger, 1989: 163). This concept has a nefarious power that is contaminating our current discourse (Furholt, 2018, 2019a, 2021; see also Hanscam here). Baked into it is the premise of a monothetic configuration of social groups, which, in accordance with Kossinna's fascist worldview, were seen as clearly bounded, static, culturally and racially distinct, and homogeneous. Agency is assumed to be collective (expressed by a strong male leader), and any kind of change is primarily portrayed as playing out between these collective units. The concept was created with the intention of proving the superiority of one or some of these 'cultures' to justify territorial claims, and cultural and militaristic imperialism. This was criticized early on (e.g. Wahle, 1941), and its ideological closeness to Nazi ideology was widely recognized after the Second World War (Veit, 1989; Härke, 1995).

Overall, the concept of archaeological cultures has been utterly deconstructed time and again (Childe, 1933; Clarke, 1968; Lüning, 1972; Hodder, 1982; Shennan, 1989; Wotzka, 1993; Müller, 2001; Roberts \& Vander Linden, 2011). Yet, many scholars (e.g. Childe, 1933; Lüning, 1972), probably the majority, claim that it may be possible to maintain the archaeological culture as a useful heuristic tool for classification, stripped of its ideological connotations. This has now, I would argue, terribly backfired. The ideological baggage of the archaeological culture is so strong that it continues to contaminate the archaeological discourse today, as illustrated by two recent examples.

To move the discussion about thirdmillennium migration forward, Kristiansen and colleagues (2017) proposed a more sophisticated migration model than the one initially constructed (Allentoft et al., 2015). This is a good piece of academic work. It discusses social processes of human movements, features specific migrating groups as subunits of 'Yamnaya', uses anthropological models, and explicitly theorizes what effects migratory processes would have on the archaeological record. It does, however, take the archaeological cultures' of the third millennium BC 
(Yamnaya, Corded Ware) as a starting point, although these do not play a central role in the model Kristiansen and colleagues present. Nevertheless, the conceptual baggage comes to the fore when all nuance is stripped away in the model's popular adaptation (Barras, 2019), which presents a simplified narrative not far from the one criticized above: hordes of young men from the east, who are referred to as both culturally and biologically distinct, invade Europe, kill all the local men and mate with the local women. Likewise, a scientific paper concerning the population history of the Iberian Peninsula (Olalde et al., 2019) was used by the popular media to present a simplified narrative of invasion and genocide, prompting a concerted critical response by a larger group of archaeologists (Valera et al., 2018).

In both cases, good and genuine scientific work was too easily turned into narratives of culturally and genetically distinct groups collectively acting and fighting each other to extinction. Such narratives are troublingly close to the worldview of many far-right, anti-humanist ideologues, and are already being exploited by such actors (as discussed in Frieman \& Hofmann, 2019). At the core of most neo-fascist or white-supremacist ideologies is the belief that today's socially constructed, historically situated identity groups (nations, ethnicities, races) are based on biological differences, and that these biological differences entail differences in characteristics and abilities, making one group superior to others. Additionally, women are seen as inferior to men, and as less important social agents (see Frieman \& Hofmann, 2019). Furthermore, this ideology is built on the belief that there was and, indeed, should always be, competition between these groups and that the superior group should prevail and survive at the cost of the others. This worldview represents a targeted attack on the humanist core of the humanist Enlightenment project (e.g. Mason, 2019). Such a portrayal of prehistory as a 'clash of cultures' scenario with racist and sexist undertones, would lead a regular newspaper reader to gain the (erroneous) impression that this fascist worldview is supported by hard science and archaeological knowledge (Frieman \& Hofmann, 2019).

Clearly this is not the intention of the geneticists and archaeologists involved. It is instead the result of a structural problem, brought about by the ideological baggage ingrained in the tradition of archaeological thinking, most clearly encapsulated in the dominant concept of the archaeological culture. The archaeological culture does not only, as many works have demonstrated, blatantly misrepresent the archaeological material (Müller, 2001; Vander Linden, 2006; Furholt, 2009), it also has never been and can never be a neutral tool for classification because it presupposes a monothetic structure of human groups, which is an ideological credo of the political right wing. Using the concept predetermines the outcome, which is a prehistory made up of monothetic units, easily translated into the idea of a prehistory consisting of distinct peoples. As we have seen, this is re-emerging in the new archaeogenetic studies. It shows the concept reproducing itself.

More than fifty years ago, David Clarke (1968: 300) suggested polythetic classification as a feasible alternative method. This avoids the ideological, monothetic premise and is much better suited to identify all kinds of settings in the archaeological record. It can create units of different shape, connected to different intersecting spheres of social practices and things, and identify sharp or blurred borders between units; it is thus much less susceptible to the erroneous equation of archaeological units with a specific bounded group of 
people (Furholt, 2019b). To give an example, in the case of the third-millennium $\mathrm{BC}$ mobility discussed above, only a polythetic approach can show that the new genetic component (steppe ancestry) identified in burials labelled Corded Ware and Bell Beaker is actually connected to a new set of burial expressions rather than specific forms of material culture (Furholt, 2019a). This provides a more detailed insight into processes of mobility and social change than the monothetic model. Although Clarke's polythetic classification has been cited and recommended repeatedly (Eggert, 1978; Lüning, 1979), its application is more rarely seen (Müller, 2001; Vander Linden, 2006; Furholt, 2009). It seems that this lack of impact is owed to the more complex picture that emerges from this kind of analysis even though it is probably closer to the complexity of social reality (Furholt, 2019b).

\section{Eastern Promises: Archaeology and Populism on the Periphery Martin Bača}

Populism has become mainstream again in the liberal democracies of Europe. It is certainly not hot news in the eastern part of Central Europe, but it was only after populism had its first major victories in the anglophone milieu that academics in the humanities and social sciences finally woke up and started sharing their opinions on the subject (Cox, 2017). Archaeologists are no exception here and are appealing for radical action in defence of liberal democracy in its full sense (González-Ruibal et al., 2018), critically analysing Brexit, predicting the post-Brexit era (Schlanger, 2018), or fighting to save the project of the European Union (Popa, 2019).

Populism today is no longer an amalgam of masses disillusioned with liberal democracy. Today, it is organized by well-funded and well-structured political parties. These populist parties are more than just vehicles for votes (Steenvoorden \& Harteveld, 2017); their supporters share an ideology (Golder, 2016) which is often fuelled by falsely constructed narratives of the past and the future. While populists in the past pioneered the misuse of mass media, especially radio and films, today's populists are skilled manipulators of social media such as Facebook and Twitter (Wodak, 2015). Social media are full of hate and the misapplication of language and vocabulary. Their management is ruefully weak in making their environment safe from harmful narratives which are often constructed and fabricated by anonymous entities. It is now fully recognized that Brexit was heavily influenced by this particular weakness of the social media; the mythical narratives of the past directly involving the topics covered by archaeology were part of the Brexit movement discourse and were misused for constructing political identities (Bonacchi et al., 2018).

Once again, we are reminded that, whether we like it or not, archaeology is and always will be political (Shanks \& Tilley, 1987; Trigger, 1989 [2006]) and the past is prone to misuse. I fully agree with the effort of my colleagues to directly engage archaeologists in fighting populism (Gonzáles-Ruibal et al., 2018; Popa, 2019) but, even if the menace is the same, the battlefield is rather diverse across Europe. I suggest, and will explain here, that some countries of the former Eastern Bloc, exemplified here by former Czechoslovakia, are fighting this war on a different footing.

\section{Basic framework}

In What is populism, Jan-Werner Müller (2016) provided a useful methodological tool for identifying populist agendas in 
contemporary political, social, and academic discourse (see also Taggart \& Kaltwasser, 2016). The key attributes of populism, according to Müller, are criticism of the elites, anti-pluralism, moral superiority, and identity politics.

Most of the populism we see corrupting liberal democracies today is linked to various far-right movements and far-right political parties (Golder, 2016). In their reactionary nature and the mythical and idealized version of the past they pursue, they are dauntingly close to Fascism.

Far-right populism is, admittedly, not the only type. Former Czechoslovakia provides us with a clear example. Although a beacon of liberal democracy during the interwar period in Central Europe, Czechoslovakia was sacrificed first to Nazi Germany and then to the communist Soviet Union. While people were not widely exterminated as in the Nazi era, the enemies of the state, of 'the people', were still named, hunted, and persecuted. The chief goal of the communist regime in Czechoslovakia was the same as that of Nazi Germany: to control, oppress, impose, and dictate the official state doctrine. Both regimes feared the free academic institutions as much as they feared the free press and free cultural institutions. A free-thinking intellectual was an enemy of the state, and free speech was feared the most. The language of the academy therefore had to be the language of conformity, of empty praise to the regime, of empty praise of the people, and of hate towards others (Krekovič \& Bača, 2014). But more important than what was said was what was not and could not be said; intellectuals in unfree regimes had to be made to believe what the state wanted them to believe and speak only as the state allowed them to speak.

Imagine you endure this for decades, for almost half a century. Imagine, further, how much time it takes to heal such a society, to rebuild the pillars of liberal democracy once again.

\section{Implications for archaeology}

Voters who are socially frustrated are attracted to the nostalgic nature of populist ideologies (Golder, 2016; Steenvoorden \& Harteveld, 2017) and often exploited by far-right movements and political parties that provide false narratives of a great past. This phenomenon is understood in archaeology mostly through the prism of nationalism (Brück \& Stutz, 2016). While this is certainly also true for Slovakia (Krekovič, 2007), populist narratives both there and in the Czech Republic are also especially nostalgic of the communist era. It is a shared phenomenon typical of post-communist countries of the former Eastern Bloc, constantly fuelling utopian dreams of a new, better tomorrow (Velikonja, 2009). While Western liberal democracies are seen as suspect and the USA as a dangerous entity by a significant percentage of the population, there is relatively high praise for the ruling Russian government in former Eastern Bloc countries (Globsec, 2018). Many people are thus prone to believe official state propaganda of pan-Slavic tendency, pseudoscientific movements (Čižik \& Masariková, 2018) and 'antifascist populism' that has nothing to do with real anti-Fascism. Finally, and most importantly, this holds true not just for the population who remembers the communist era, but also for the young who did not experience the communist regime at all. It is most significant in countries which are already governed by populist parties with totalitarian attributes, such as Poland and Hungary (Globsec, 2018).

A key task for archaeologists is to engage against populism on multiple fronts. First, it is necessary to realize that 
populism is related to a crisis of political identity (Müller, 2016). In the eastern periphery of the EU, the recent past brings back multiple traumatizing memories, including: the Holocaust; the displacement of whole population groups who had lived there for centuries (i.e. Germans in former Czechoslovakia); the restriction of freedom; collectivization; the uncontrolled and brutal entry of capitalism after the fall of communism, which led to increasing poverty and organized crime; the abandonment of Roma people; and environmental issues. These events left unhealed scars which we must bear in the increasingly faster-moving and more globalized twenty-first century.

The past, the present, and the future are intertwined and the same applies to archaeology. Ideological restriction and non-existent freedom of speech and/or research led to a theoretically underdeveloped archaeology. I believe that this theoretically underdeveloped archaeology has serious limitations for sufficiently explaining the many sensitive issues of the twentieth and twenty-first centuries to the general public (see also Gramsch, 2011). It is unacceptable for archaeologists, who are among the most competent at explaining the past, to leave this field to amateurs and politicians. Beside a more developed theoretical archaeology, studies dealing with the age of modernity are largely missing. We need to better understand the struggle against Fascism in the 1940s and the extent of collectivization in the 1950s. We need to remind ourselves about the German minority that significantly contributed to the culture of eastern Central Europe. We need to acknowledge the Roma people, another forgotten but everpresent ethnic group with a seriously broken identity. In the eastern periphery of the EU, we finally need to acknowledge women and other marginalized groups, be they of race, faith, or sexual orientation.
We must banish the growing antagonism. We can no longer allow populists to dominate the political discourse with concepts borrowed from the humanities (Laclau, 2005), in our case archaeology. We need to replace the concepts that are abused by the populists with new, human-friendly content (see also Rybár, 2020). So, when archaeologists speak, they will also speak with the language of the forgotten.

Finally, archaeologists from the former Eastern Bloc countries should remind other countries what happens when academic freedom is lost to populism. It is an invaluable experience and should be disclosed whenever necessary.

\section{Conclusion}

It may seem that archaeologists are engaged in a hopeless fight against this tsunami of populism in the early twentyfirst century. Milan Kundera (1984), in an influential essay titled 'The tragedy of Central Europe', wrote that the real tragedy of Central Europe was not the Soviet Union but Europe itself, because it no longer perceives itself as a value. Not so much has changed and the European Union, which should represent the essence of what it means to be European, is increasingly seen as a burden. The current situation is, therefore, not the fault of governments outside the European Union, who may or may not support the populist parties in Europe. It is our fault.

Former Czechoslovakia is a typical example of an atmosphere in which populism was reaching its final stage. Contrary to most Western countries, both countries of former Czechoslovakia have direct experience with two totalitarian regimes known for their heavy populist agendas lasting almost five decades, as have surrounding countries such as Poland and Hungary. Half a century of populism has 
left its mark on the population, which eagerly listens to the populist agendas of today. Contemporary populist narratives in these countries are a mix of far-right and far-left ideology and vocabulary. Therefore, when new narratives of eternity (Snyder, 2018) emerged, some were shocked because they remembered the past, and some listened closely because this is exactly what they wanted to hear again.

Attacking academic freedom should be seen as an act of violence against democracy. Maybe we should again shame and discourage governments that flout academic and political norms which are crucial for liberal democracies. A free academia is one of the pillars of liberal democracy and it loses its legitimacy when the populist agenda attacking it is not countered. As history has taught us, every time there is a move against academic institutions, the humanities and social sciences suffer the most.

While there are hundreds of wellwritten papers dealing with the social and cultural welfare of people, and while academics around the globe are working hard for a better understanding of humanity and for a means of fighting populism of any sort, most of their papers are hidden behind paywalls. Capitalism is stronger than ever, while the pillars of democracy are systematically being undermined. The papers and slogans that are harmful to democracy are free and available to everyone through social media. Academia is living in its ivory tower while most people out there have forgotten we even exist. Or in the worst case: are we the elites they are fighting against?

\section{The Archaeological Voice Samantha S. Reiter}

Hobsbawm (1992: 3) wrote 'nations without a past are a contradiction in terms'. By doing archaeology at the trowel's edge (Hodder, 1999: 92-98), we have a hand in manufacturing the past. By making history, we contribute to the building of nations. It is well known, therefore, that archaeology is and always has been political (Trigger, 1984; Kristiansen, 1993; Rowlands, 1994). Yet, since the Second World War, some subfields of archaeology have allowed themselves to be crippled by the abuses to which it was put during that era (Arnold, 1990; Veit, 2002; Brather, 2008). Since then, many scholars have locked themselves away from the political world, claiming that they want to "just do archaeology'. Unfortunately, this professed policy of non-interference is both ineffective (e.g. Wilks, 1985) and hugely detrimental to archaeology's relationship with the greater socio-political communities of which it is a part.

A recent study of European citizens showed that this professed ideal of political non-involvement runs directly counter to the public's expectations of what archaeology should be: 'The role of archaeology is clearly associated [by the public] with understanding the present and passing down this knowledge to younger generations' (Marx et al., 2017: 2). While the material subject of archaeological study may be the past, its input is both expected and sorely needed in the present. An archaeology that exists in isolation from modernity will soon make the discipline obsolete but, as GonzálezRuibal (2014: 44) puts it, 'an archaeology that is relevant helps us to think and problematize society (past and present)'. This is not to suggest that archaeologists should act as a kind of moral gatekeeper (see Popa, 2019) since 'the choice between all the potential arguments that history can potentially provide ultimately depends on the values and principles that individuals and groups decide to sustain and the 
context within which they operate' (Bottici, 2008: 54; see also Recabarren et al., 2007). Indeed, the public role of archaeology should be one in which we responsibly provide a historical framework for current debate. The director of the District Six Museum in Cape Town, South Africa, Bonita Bennett, describes the challenges of this position:

'Giving up narrative control has been... a challenge. We witness the telling of uncomfortable stories which do not always align with our institutional identity. We have to be vigilant, to resist the impulse to script and sanitize-unintentionally or otherwise, as we attempt to model a space for multiple, contested narratives' (Bennett, 2012: 322).

The role of archaeologists and of archaeology, however, need not and should not be merely to set the stage for others to interpret the results of our research and data. We can and must play an active role in this. In recent years, González-Ruibal and colleagues (2018) have urged archaeologists to rally in defence of the European Union. The underlying message of this landmark publication has global relevance: if we do not wish others to use our research to concoct unsanctioned stories or political agendas, then we need to interpret that research ourselves and must do so clearly and concisely.

In order for our voice to be heard, the medium and language of those communications should be intended for the general public rather than academia (Risse, 2004; Bond, 2018). Unfortunately, little media training exists within university archaeology programmes. As a rule, archaeologists have more experience of being the subject of media debate than being its driving force. This state of affairs must change if we are to take part in public discussion.

One scholar who has taken dissemination into his own hands is Maikel Kuijpers of Leiden University. A recent documentary he produced in association with The Craftsman Initiative entitled The Future is Handmade (The Craftsman Initiative, 2019) is both academically rigorous and profoundly relevant to present-day society, such as jobs, capitalism, and the 'user-friendly' movement. When I questioned him further about his collaboration on the project, he said, 'The medium certainly matters. One of my popular academic papers has about 3500 views now on Academia.edu. The documentary has over ten times that many views. That is a big difference in terms of impact and where that impact is made' (M. Kuijpers, pers. comm.).

Fortunately, there has been a recent blossoming of what one might call 'soft science reporting'. Some scholars have also been active in publishing reflective docudrama-style written memoirs of their research careers (Barley, 1983; Maples \& Browning, 1994; Prentiss, 2012; Willerslev, 2012; Frei, 2018; Reich, 2018), though such accounts remain too few. These types of public outreach efforts are often well received by the general public but all too often these kinds of publications are frowned on by the academic community. This unwillingness to engage has created a niche market for journalists who specialize in synthesizing the accounts of a specific area within academic research, such as Zimmer's $(2011,2018)$ two recent accounts of genetic work, or Johnson's (2015) account of archaeology. Happily, there are other possibilities for those of us who want to engage with the public but who lack confidence or need additional journalistic support to do so. The Conversation, for example, which includes articles written exclusively by researchers and academics with the aid of journalist support staff, bills itself as 'academic rigour, journalistic flair'.

It would be hubristic and naive to advocate engaging with the public and current 
socio-political affairs without making space for the conversation to flow in both directions. Pentz and colleagues (2019: 3) write that it has long been recognized that people want to take an active role in interpreting the past. The past presented "as it was" through a single lens of interpretation that excludes other voices easily becomes arrogant'. As modern archaeologists, we are the lucky heirs to the arrival of multimedia to new museological approaches and new generations of the web (Hoffos, 1992; Halpin, 1997). In addition to collaborations between amateurs and professionals such as the Danish Danafæ and the British Portable Antiquities Scheme, examples of the shift to user-generated content include the Danish National Museum's Din Ting/Vores Historie (Your Things/Our History) as well as the 2020 En skat til Danmark (A Treasure for Denmark) exhibition, the British Museum's History of the World in 100 Objects and the British Museum and University College London's collaborative MicroPasts project (see also discussion in Frieman \& Wilkin, 2016). Including the public in what we do is just as important as discussing results openly in a public setting. Archaeology as an interface between politics and the public can do more than educate and entertain; it can challenge our present ways of thinking and make us examine the entirety of who we were, who we are, and who we might one day like to be as a society.

Engagement with the past is a dirty business. If we want history to be relevant today, we cannot set it on a pedestal. We need to interact with it, play with it, debate it, and think with it. Ideas about the past evolve, so our engagement with them should too. There must be room for error since this is how we will collectively learn about the past and from the past. Through our interpretations of the pastand our engagement with it-we make it ours, we make it about the present, and we make it something to think with. How we do archaeology and how we present the past to the public involve negotiation with the present, and each time the results of an archaeological study are published those words echo far. Archaeologists may not speak as one, but archaeology has a voice. Let us use it.

\section{Populism in Italian Archaeology Alessandro Vanzetti}

In Italy, archaeology is seemingly not particularly relevant for populist feelings; nevertheless, some significant populist entanglements exist, which intertwine with longer-term political and economic trends (Pulselli et al., 2019).

Populism in its present-day form has substantially replaced the corporate and class struggle typical of the late nineteenth and twentieth centuries, and populist arguments were already strong in the growth of Fascist and Nazi dictatorships in Europe; they also generally supported autocratic governments of the Soviet bloc.

Sketched out roughly, populism is now a typical post-ideological behaviour (Aslanidis, 2016). As a 'thin-centred ideology' (Stanley, 2008), it is mutable and can 'be easily combined with very different (thin and full) other ideologies' (Mudde, 2004: 544), such as Socialism, Liberalism, Fascism, and so on. As populism relies on people, it appeals to the personal interest, or sometimes selfishness (or even greed), of individuals or independent corporate groups, fitting coherently within the present-day capitalist world. In political terms, this is the consumer-voter perspective, as a direct (populist) relation is stimulated between the individual's choice and the producer's or politician's decision (Schwarzkopf, 2011). The anarcho-individualist approach (different from social anarchism) is a relevant populist attitude, but what principally 
characterizes present-day populism is the self-centred view of personal appropriation and defence of property.

A basic aspect of populism is the stated distinction between 'the pure people' versus the 'corrupt elite' (Mudde, 2004: 543; Boeri et al., 2018), whereby the 'pure people' are a loose and mobile interest group. The people/elite divide is, in fact, the first 'ideological regularity' of different populisms (Galli \& Garzarelli, 2019). The three others are: nationalist orientation (from separatist to whole-nation), promotion of short-term policies based on demagogy, anti-immigration and anti-globalization pressure.

In politics, Italy is characterized today by strong populist tensions, which have evolved over a considerable number of years. They are mainly expressed by two political parties: the League (formerly Northern League), which moved from a separatist position based in northern Italy (1989-2017) to a nationalist, sovereignist Italian perspective (since 2017), and the Five Star Movement, founded in 2009, which sees itself as neither left-wing nor right-wing.

Within archaeology, four types of popularizing communication and practice can be identified, as outlined in Table 1. A-type academic communication is challenged by C-type arguments, which see institutional archaeology and history as elite-driven and masking the truth in order to keep control, or for mysterious goals. The B-type represents the politicallydriven support for some kind of historical identity against other choices, as a myth of purity, perfection, or lofty ethnic and cultural values. The D-type is practised by non-professional archaeologists acting as gifted interpreters, surging to the forefront against the elite represented by official archaeologists or historians. These interpreters start from the bottom up, but soon acquire a kind of A-type top-down narrative, promoting their alternative versions.

\section{Archaeological populism in Sardinia}

Sardinian archaeology has long been entangled with local autonomist or separatist issues centred on the 'constant resistance' of Sardinians against invaders (e.g. Lilliu, 2002). Nowadays, Sardinia is a marginalized region with an evident divide between the touristy coast and the impoverished inland (Vanzetti, in press). A clear contrast is visible between diverse and permeable groups of local historians and self-claimed experts (type $\mathrm{C}$ attitude) and official archaeologists (represented as the elite). This is particularly evident in the interpretation of Bronze Age Nuragic society. The elites are believed to hide and distort the evidence of Nuragic strength and greatness, as well as proofs of early astronomical knowledge and writing. Consequently, discussion of the Mediterranean connections of the Nuragic Late Bronze Age is often removed from the debate, as there is an (official) fear that it could create dangerous links with the so-called fanta-archaeologists (fanta being an abbreviation of fantasy/fantastic: D’Oriano, 2014).

Some popularizing experts of D-type stress the anti-elitist divide, the most prominent being the journalist Sergio Frau (2002), who claimed that Sardinia could be identified with Atlantis, ultimately destroyed by a Bronze Age tsunami (Evin, 2015). Frau's approach was taken up in the top-down populism of political origin (Btype), with support from the Sardinian regional government and from UNESCO representatives, who sponsored exhibitions in high-profile venues such as the Maison de l'UNESCO in Paris in 2005 or Cagliari airport (2017-2018). Frau has claimed support from official archaeologists and from geologists who endorse the tsunami theory explained in his bestselling books. In November 2020, a television programme on the Italian State Channel RAI 3 re-hashed the theory, first 


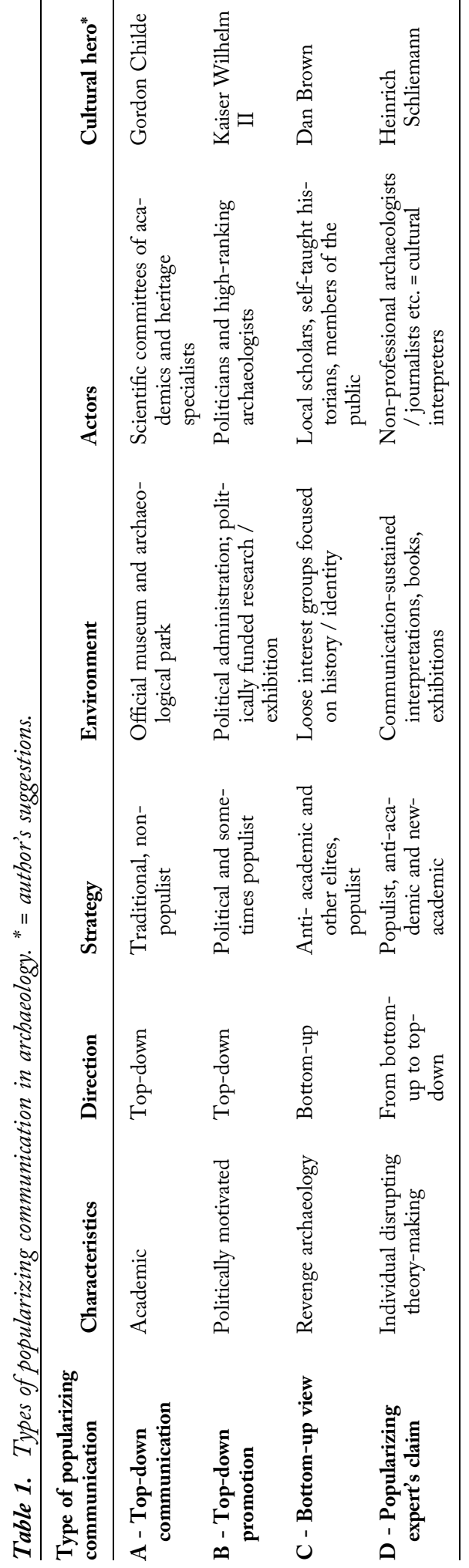

broadcast in 2002 and involving the same geologist, Mario Tozzi, as partner and supporter.

\section{The Calabrian passion for purported megaliths}

In Calabria, an Italian region with some of the lowest economic and welfare indicators and a strong mafia-like illegal presence (the 'Ndrangheta), some impressive rock outcrops have been labelled as humanmade 'megaliths'. This C-type attitude is sustained by local volunteers, historians, and scholars, sometimes even including geologists or fully-fledged archaeologists. In some cases, the megalith supporters attract the attention of the local administrations in a populistic process stimulating small-scale B-type interventions, as in Sardinia. No archaeological remains have - so far-been found in connection with these definitely natural monuments (Johnston, 2002). In this case too, but less strongly than in Sardinia, the underlying message is that official archaeology chooses to hide important evidence of local greatness and a powerful past, which, populists argue, would generate income from tourists.

\section{Creating a Celtic identity in northern Italy}

A mythical past-this time concerning a unified Po plain identity named 'Padania'-is foundational to the Northern League party (now League party; Albertazzi, 2006). The party think-tanks proposed the Celtic past as the unifying national phase of northern Italy: Celts settled there after migrating across the Alps and even defeated and sacked the hated central power of Rome in 390 BC. The native descent of the Padanians had 
to be recognized in a proud, independent, and anti-Roman people. One strategy involved the promotion of public celebrations of 'Celtic' identity, such as Celtic festivals with re-enactors, Celtic music, and historical foods. More complex archaeological elements, such as the variety of ethnic components in the Po plain or the different cultural history of the Venetian region and its strong ties to Rome, were downplayed. The Northern League also offered a special provision of four billion Italian lire (more than two million euros) as part of their populist 'Celts Project' (Friuli-Venezia Giulia Regional Law 2/ 2000). Although some state and university archaeologists were able to broaden the spectrum of research beyond these narrow goals, the result has indeed been a strengthening of populist feelings towards a Celtic past, which spans only three to four centuries of local history. Indeed, in 2001, Trieste, the capital of Friuli-Venezia Giulia, launched the active and popular Celtic Triskell Festival. This sort of populism in the form of festivals can be understood as a mix of political top-down and revenge bottom-up B- and C-type actions (with some pseudo-Celtic feelings) and pure enjoyment.

\section{Conclusions}

A roughly Marxist analysis proposed some years ago regarding the populist attitudes of Sardinian (and Calabrian) revenge archaeology noted the connection to regions suffering social fragmentation and economic and cultural marginalization (Pulselli et al., 2019; Vanzetti, in press). The two situations are different: Sardinia has an average GDP higher than the other southern and island regions of Italy, but a fundamental divide exists between the towns and tourist coast and the socially fragmented and economically impoverished hinterland. The idealized revivalist (and revenge) aspirations of the local population develop in this context, where archaeological looting, aimed at finding bronzes to be sold on the illegal market, notably the bronzetti figurines, is still widespread.

Calabria, by contrast, is one of the poorest regions of Italy, with a strong 'Ndrangheta criminal element, and revivalist/revenge archaeological dreams (less acute than in Sardinia) are likely to be connected with both frustration and positive aspirations. Admiration for the greatness of the archaeology of Magna Graecia is strong, as is the search for extraordinary findings in less spectacular earlier periods. Illegal excavations and looting are also frequent.

The pressures of B-type Celtic populism were stronger when the Northern League had a clearer autonomist/separatist position. This focus has now reduced. By contrast, while Italian nationalist populism could reclaim a Roman tradition, this is as yet underdeveloped even by right-wing, post-fascist parties, possibly because of the pan-Mediterranean and European heritage of the Roman Empire.

In sum, the populist forces' relative lack of interest in archaeology and the strength of the academic and heritage sectors have so far limited the use of Italian archaeology for populist discourses, and the existing cases can be read through the economic lens of local development.

\section{From the Nation's Archaeology to Archaeology's People Kostas Kotsakis}

I am writing this note in 2020, while many Brexiteers celebrate Britain's official exit from the European Union and, in the United States, Donald Trump's support does not wane despite his unprecedented obduracy to accept the 2020 presidential election result and his pending 
impeachment trial. These are the outward signs of the populism that sweeps the world, West and East. It is no longer just some people believing in outrageous conspiracy theories. Racism, sexism, xenophobia, and revisionism have cast a heavy shadow on politics, emphatically showing that this wave leads to politically dangerous waters. Between tragedy and farce, populism threatens the core of democracy, the idea of an open society with a shared basis, as founded by modernity. Conversely, populism's crude outlook celebrates the gap between the elite and the people. Although defining populism is notoriously complicated and falls outside the present remit (De Cleen \& Stavrakakis, 2017; Stavrakakis, 2017), here I define populism as the belief that the world is structured along one simplistic, hierarchical dichotomy. Conspiracy theories are its inevitable product.

What can archaeology, with its elitist legacy, do against this current? Archaeologists need to remember that the massive appeal of fringe ideas is much more than a mistake that archaeology can correct; it results from a real lived experience of disenfranchisement and loss of dignity. These extreme views come from a simplifying distortion of a traumatic reality that directly affects people's lives. Undoubtedly, it involves a shockingly false reading of the facts but, unfortunately, this does not make the perceived reality less compelling.

The island of Lesvos in Greece can serve as a case study for archaeology's difficulty, even bewilderment, to cope with local populist politics. Thousands of refugees come to the island every year via Turkey. The state puts them in open refugee hotspots, leaving them stranded among a local population of a few tens of thousands. It is easy to see how local populists exploited this dire situation for political gain, undermining the local people's initial goodwill and hospitality that attracted much positive international attention.

The anti-immigrant feelings, fed by the inadequate management by the state, quickly led to a surge in xenophobia. Overwhelmed by the scale of events, the local authorities failed to relieve the pressure from this outbreak. Archaeology, in particular, was not prepared to engage with people from vastly different cultural, historical, and social backgrounds. The numerous NGOs involved in educational and cultural activism did not include archaeology in their plans, nor did other institutions, e.g. the university on the island. The example of Lesvos makes us wonder whether archaeology, as practised, has any part in the battle against populism. Possibly, as Hamilakis (2018) has proposed, archaeologists should resort to political activism but, although I do not underestimate political action, I doubt that it will answer archaeology's problem.

One tested and increasingly employed archaeological tactic of engagement revolves around 'heritage' (see other contributors to this section). Like museums, which have evolved from national treasuries of the past into educational centres cum amusement parks, archaeology has turned to cultural heritage as a social obligation and an almost mandatory way to meet the public (see critical discussion e.g. in Waterton \& Smith, 2010; Winter \& Waterton, 2013). Heritage is considered a public good by definition. The idea is that the attractively documented presentation of the past will automatically illuminate the audience. Yet this optimistic scenario never happens in real life, as the proliferation of post-truths and conspiracy theories channelled through the media proves.

Like historians (Kalela, 2012), archaeologists have always selected their audiencesreal or imagined-and archaeology has been comfortable speaking to one assumed 
unified national audience. In today's selfreflexive spirit, the selection is neither innocent nor straightforward; many different audiences are out there. Laclau (2005: $\mathrm{ix}-\mathrm{x}$ ) explains why: society is not a harmoniously functioning whole but a 'constitutive impossibility' that contains an endless contradictory movement. The result is smaller, fragile entities, which Laclau calls demands. Demands cluster around absences-perceived or real-in social relations: inclusion where there is exclusion, justice when there is injustice, etc. In other words, society comprises many different groups of people with differing agendas.

Knowing our audiences and their demands is, therefore, the priority when dealing with a populist discourse. In the Paliambela Kolindros project (Chowne et al., 2007), the aim was to involve the local rural community in managing an Early Neolithic site (c. $6600 \mathrm{BC}$ ). We first surveyed the local people's perceptions and mentalities, exploring how they saw archaeology. We used questionnaires, filmed interviews, and conducted a systematic ethnographic study of the population (Parlani, 2014). Only then were we able to target our activities to specific groups. The diversity recorded helped us think beyond the strictly archaeological subject and gave us the possibility to design a management plan that allocated activities, narratives, and interpretations based on people. González-Ruibal et al. (2018: 508-09) have rightly cautioned against the dangers of underestimating the diversity of audiences with which archaeology wishes to engage. Our experience with the small group of people of Paliambela shows that defining our audience's diversity makes it possible to connect people with the materiality of objects and re-establishes ties and memories of their own lives. An Early Neolithic sickle blade presented to senior community members drew out lifelong harvesting experiences and informed our archaeological interpretations. It was a moving spectacle to see elders retrieve their old, unused sickle and proudly perform a harvesting demonstration (Halstead, 2014: 77-121 and figs 3.7 and 3.8). Similarly, a Neolithic grinding stone brought memories from childhood and raised questions of gender, labour allocation, and cooking. Without resorting to elite knowledge, we engaged people of different ages and genders with our archaeological project to benefit both.

Meeting the challenge of identifying the 'stakeholders' is crucial to empower the public. Lamentably, archaeology's relations with its audiences have long been dominated by cultural elitism, in other words, by the fetishization of expert knowledge. Cultural elitism, which disregards the actual people in the present, has been sharply criticized in the heritage debate (Waterton \& Smith, 2010; Winter \& Waterton, 2013). Nevertheless, expert knowledge is still considered central by archaeologists who feel that the communities' involvement exposes them to the risk of becoming 'just another interest group' (Smith \& Campbell, 2018). At the opposite end of the spectrum stands what has been called 'epistemic populism', a term with negative connotations signifying the readiness to consider knowledge produced from communities as epistemic, subaltern knowledge (Grosfoguel, 2011). As a justified reaction to the exclusion of communities from their heritage, multiculturalism and multivocality need not lead to epistemic populism if applied in a context of dialogue and mutual understanding, as at Paliambela Kolindros. Again, getting to know the audience helps overcome the ethnocentric and essentializing prejudices of archaeology.

In effect, archaeology must become less narcissistic and renounce its urge to hegemonize all discourse about the past, thereby disempowering people (Stavrakakis, 2017). 
González-Ruibal et al. (2018: 507-09) refer to people who, although exposed to archaeology and modernity, do not have an official notion of heritage or are entirely indifferent to it. In a pilot ethnographic field study intended to investigate attitudes towards the cultural landscape in six villages in northern Greece (Tryfinopoulou, 2010), we found that the communities, mostly descendants of refugees from Anatolia who arrived there one century ago, could not identify anything of cultural significance in their region. The only exception was one specific location said to be reminiscent of the fields around the ancestral village in Turkey. Given the Greek state's tight control on heritage and archaeology's critical role in supporting national narratives (Kotsakis, 1998), such a lack of interest in the official heritage narrative is puzzling.

It may be that the hegemonic state control of heritage (in Greece, archaeology is exclusively a state service) had not penetrated these communities yet. Alternatively, local identities determined by the scale and nature of the communities' conflicts or demands (e.g. refugees vs local people) opposed the official narrative. Either way, exploring the public's attitudes towards archaeological heritage is a priority (Kajda et al., 2018), principally since state archaeology in Greece has so far been reluctant to abandon the well-established encultured nationalism of the nineteenth century and continuing to the present day (Kotsakis, 1991; Hamilakis \& Yalouri, 1996; Damaskos \& Plantzos, 2008). In this respect, I believe that distancing from state and nation narratives will become essential to counteract narratives that both end up reinforcing parochial accounts or populist agendas.

As archaeology's symbolic capital in an advancing global, predatory capitalism is rapidly diminishing, and its 'use' for validating the national narrative is fading (populists just do not need it), archaeology must redefine itself and reform its practices. If working with our audiences has become our primary obligation, including media and institutions (Bernbeck \& Pollock, 2018), but especially algorithms that widely disseminate 'posttruths', the new mission is to know all these in depth. In this presentist objective, a sensible strategy is to seek the cooperation of experts so that the archaeological task is not demoted. As González-Ruibal (2018b: 18) remarks, it is not really useful to take the robes of other disciplines: anthropologists do better anthropology and historians better history than us'. Given that the scope of Greek state archaeologists' duties and activities are strongly regulated by the state, and since there are no freelance archaeologists, such external cooperation may be our only realistic chance. In this dystopic contemporary political landscape, archaeology and archaeologists must reflect on the gambit between dispelling populism and a drastic re-evaluation of archaeology's interaction with society. Otherwise, political populism will become cultural and rapidly consume the 'public' irrevocably.

\section{Commercialization and Populism: Vikings and Public Outreach Activities IN Norway Håkan Petersson}

One aspect of populism and archaeology is the commercial use of archaeology by the popular cultural tourism industry all over the world. In Scandinavia, the Vikings are more attractive than ever, particularly in relation to cruise tourism. Cruise ships are an essential part of the tourism sector in western Norway. In Stavanger alone, a town of approximately 120,000 inhabitants, some 300 cruise ships brought an estimated 500,000 passengers in 2019, generating considerable profits. To attract cruise ships, a port must offer unique 
experiences. Tourist activities, therefore, are of great political and commercial interest as stops to compete for cruise liner traffic. To this end, exciting stories of seafaring Viking explorers and brave warriors have increasingly become the focus of government institutions, private commercial interests, and museums in Norway. At the official institution Visit Norway, Vikingrelated sites rank among the top tourist attractions (https://www.visitnorway.com/ things-to-do/art-culture/vikings/top-sites/).

In the Stavanger area, the focus is on the Norse sagas' description of the Battle of Hafrsfjord. The Battle of Hafrsfjord in AD 872 is described as a bloody sea battle between Norwegian chieftains, in which the losing side was slaughtered (Fidjestøl, 1993; Titlestad, 2011). While most research regards the consolidation of Norway as taking place about 300 years after that battle, local historians (Titlestad, 2011, 2018; Grøsfjeld, 2018), interest groups, and other stakeholders (Risa, 2018) paint the battle as key to the creation of the Norwegian kingdom, in an attempt to capitalize on the Vikings for tourism purposes (Figure 1).

The Viking stereotype sold to the public focuses on a courageous, androcentric society, steeped in violence and based on pillaging. Yet, almost everything about the battle is uncertain: its location, the way it was fought, whether it really was a battle, whether it was fought on land or at sea. The opponents are even said to have come in knarrer, i.e. trading ships, rather than the warships one might expect. The story told by the archaeological evidence is much more variable. There are indications of possible maritime looting, in the form of Irishmade prestige artefacts, but otherwise most of the material indicates wealthy burials, self-supporting farmsteads, local craft production, and indications of regional trading sites. When considering gender issues, the region also has very rich female graves, such as the 'Gausel queen', Norway's richest female Viking Age grave (Børsheim \& Soltvedt, 2002: 179-93).

\section{The commercialization of national identity and cultural heritage}

The focus here is not the historical accuracy of the sagas, but the use of the battle and Viking stereotypes as commercial tools, that is capitalizing on history for political and/or economic purposes. The latest example of this phenomenon was when politicians and tourist providers proposed a new, large visitor centre on the shores of the bay of Hafrsfjord (Risa, 2018). The goal was to create a public arena to attract tourists to the alleged battle site, reinforcing the importance of the region in Viking history and in the establishment of the Norwegian kingdom, and emphasizing the Vikings' political influence in Western Europe.

The Viking House, a privately funded, commercial attraction located in the harbour next to the cruise ship disembarkation point is another initiative. Here, visitors can purchase souvenirs and books and watch a VR-film presenting the history of the battle based on the sagas. However, these attractions are not alone. The outreach activities of Stavanger's Museum of Archaeology also cater for what is popular, focusing on the Vikings. The museum's Viking exhibition, while generally nuanced, flirts with the dominant Viking stereotypes while avoiding addressing the issue. Instead of contrasting popular images of history with empirical facts, little explanation is offered for pieces such as a berserker podium (Figure 2) placed in an exhibition focusing on wealthy female graves. While the exhibition was remodelled in autumn 2020 and the podium moved, it is still there and the bookshelves in the shop still present a traditional, androcentric view. 


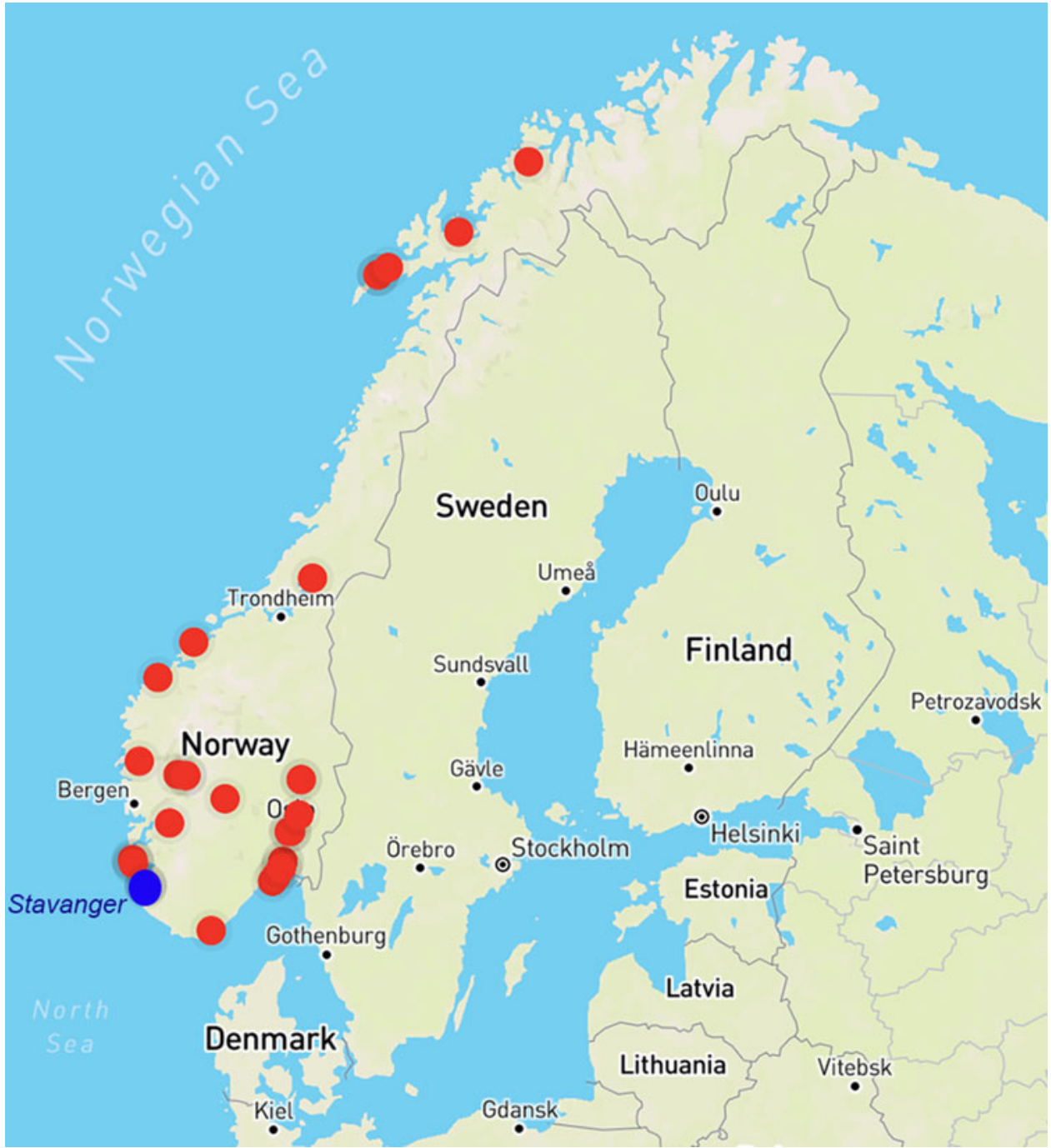

Figure 1. Map of major Viking Age visitor sites in Norway. Stavanger emphasized in blue (extracted from www.visitnorway.com).

\section{The Vikings, a Scandinavian tourist brand?}

Even though Viking tourist attractions use the same rhetoric as earlier political nationalists, the use of the Vikings has shifted from reinforcing national identity to economic opportunism. What can be capitalized on is politically and economically attractive, and what sells seems mostly to be the same brutal, androcentric narrative that has prevailed since the period of national romanticism. Fifty years of modern research and archaeological discovery appear to have had little impact. These Viking stereotypes are part of our identity and are now used by the tourist sector-government-funded organizations, commercial enterprises, tour providers, and open-air heritage parks - as the cultural brand (Holtorf, 2007) of western Norwegian history. These agencies' goal is 


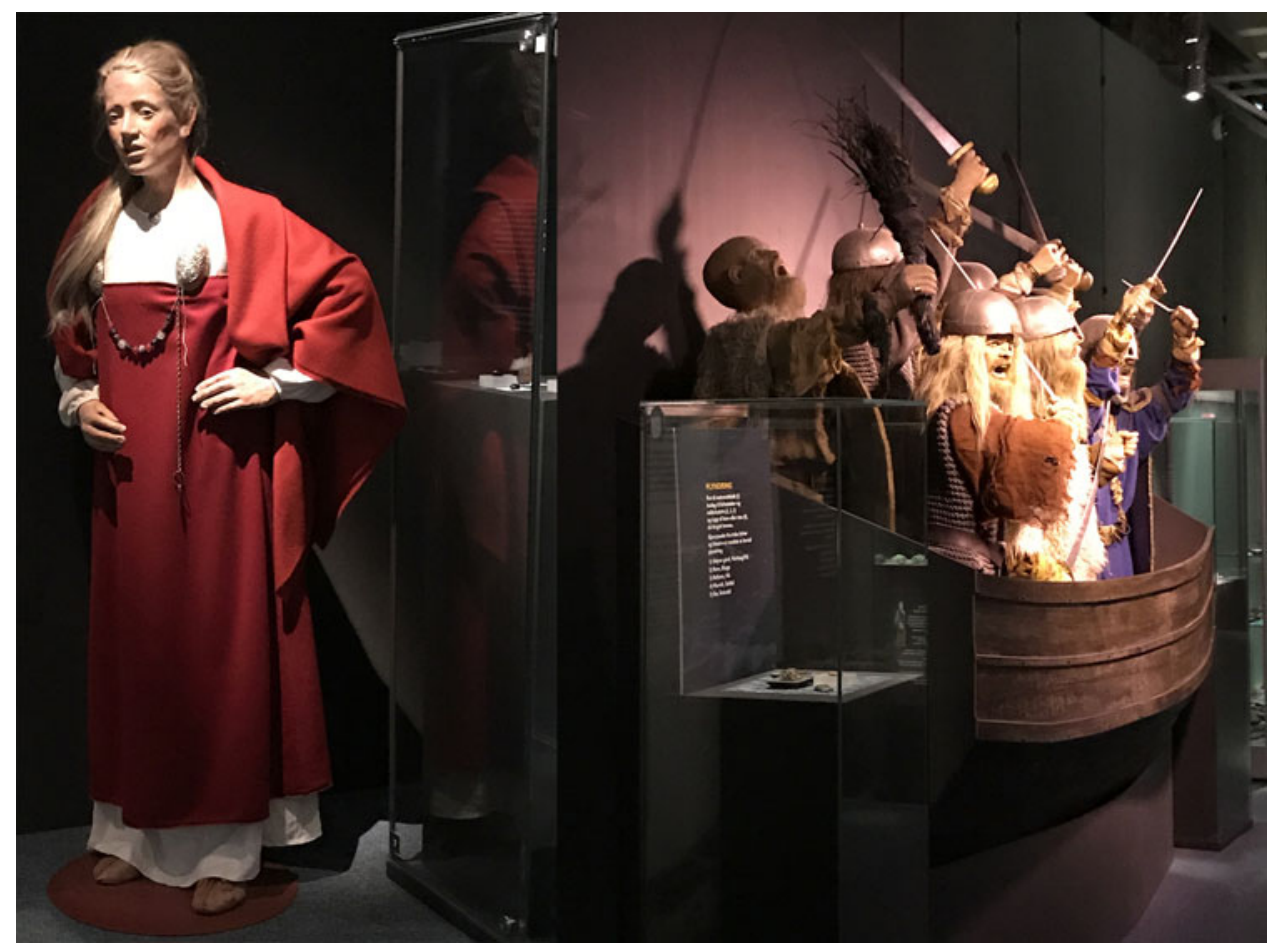

Figure 2. Podium showing warriors in the rage of battle ('berserkers'), and interpretation of female graves at the Stavanger Museum of Archaeology (photograph: H. Petersson).

to attract capital and interest to the region, since tourism is an important financial sector.

This outreach environment is, whether we like it or not, forcing museum professionals to adapt. Our institutional hegemony as interpreters and exhibitors of history is gone. The situation is escalating, and I feel that the response of my former employer, the museum, and similar institutions, shows how unprepared the sector is to address these questions. We oppose such developments and at the same time compete with new players to attract the public.

Should we rather work with commercial outlets to ensure that a more comprehensive image of the Viking period and Norwegian history as a whole is presented to consumers? Museums and academic representatives of knowledge- based interpretations need better strategies to function in an environment which mostly caters for what is popular. This requires a more developed, critical methodology and theoretical awareness, a goal yet to be achieved. Research principles from academic fields such as museum studies are poorly integrated in the collective outreach awareness, which is built more on traditional academic disciplines and ideals and the need to attract the public.

\section{Self-awareness at the museum}

The actions of museums seem to reflect frustration at not being the main outlet chosen by politicians, government organizations, and tour providers for promoting Viking history, as well as showing that 
they are ill-prepared for dealing with the academic aspects of the situation. It is also frustrating that research-based knowledge has so little influence over what is popular. Once again, it is something museums do very little to resist, instead steering much of their outreach activities towards that same populism to compete for visitors.

Instead of the proposed new visitor centre at Hafrsfjord, the Stavanger Museum suggested using its own open-air historical park, Jernaldergarden (Iron Age Farm), a reconstructed Migration-period farmstead on Hafrsfjord bay, as a centre for public outreach on the Vikings and the Battle of Hafrsfjord (Madsen, 2018). In doing this, the museum should have reflected on what narratives are constructed when presenting mixed historical facts in public outreach and how a knowledgebased accuracy in outreach activities can be retained. Instead, the museum chose to use the farm as an arena for an increasingly popular view of the Viking Age.

To me, it feels like territoriality. A new Viking visitor centre only $500 \mathrm{~m}$ away from the Jernaldergarden would seriously threaten attendance numbers, easily making the attraction economically untenable. I would suggest that letting the Migration period be what it is and participating in a new Viking centre might have been a better choice.

In this way, we accept the loss of our interpretative hegemony in a new environment of public outreach and try to work within the framework of both the needs or goals of the tourist providers and our need for historical accuracy. Through close involvement, we are better placed to balance both sides, to attract tourists while contextualizing and addressing the anachronisms and the images of what is popular. One way forward could be to use contrasting views or ideals side by side, making people see things in the much broader context of societal development over time, and challenging our own beliefs and prejudices as visitors.

\section{Final thoughts}

As providers of an archaeological, knowledge-based outreach, we need ways to popularize other images of the Vikings than the tradition of heroic pillaging enshrined by national romanticism. We also need better ways of marketing our narratives. We need strategies for sustained collaboration with commercial interests if our goal is to promote and foster a modern, knowledgebased public perception of history in today's commercial outreach environment.

We need to be at the forefront of this. The creation of The Viking House, discussed above, is an ideal example. If, instead of being passive spectators, we had been active participants, we could have influenced the outcome, ensuring a balanced presentation of both archaeological evidence and the saga. The suggested content of the proposed visitor centre at Hafrsfjord, promoted solely by non-professional stakeholders and backed by political interests, would have served to reinforce the androcentric stereotypes to thousands of visitors from all over the world. If we focus less on protecting our own existing visitor sites, and instead actively participate in the development of new visitor attractions outside our institutions, the storytelling presented to tourists could be more comprehensive. Many of the stakeholders involved want accuracy, but they must also be able to capitalize on their efforts.

Therefore, rather than hoping that the ideas of political and commercial projects will go away, our strategy must be one of flexibility, integration, and involvement, with a focus on guiding a project towards knowledge-based presentations and interpretations.

We must also open a debate among the different views and ideals of history both in 
our engagement with the commercial tourist sector and in our own outreach activities. Rather than flirting with the popularity of the atrocities of seafaring warriors, idealized as heroic narratives and rendered inoffensive by the passage of time, we could contextualize these stories of slave traders and murderers in accordance with modern research and modern values. In the end, what difference is there between the idealized view of Viking raiders and modern murderers and slave traders? The historical memory presented is also very short. The Viking Age is the brief outcome of longterm processes extending over the course of the Scandinavian Iron Age and ending in medieval, urban society. The period of Viking raiding was an even shorter phase within this process, so let us focus on the whole picture and make it exciting.

From a modern, democratic standpoint, and to prevent offensive populism in archaeological outreach, overemphasized stereotypes should be contrasted with the evidence from history. Deconstructing them in favour of modern, humanistic narratives of history can have a long-term effect on our idea of national identity. This implies shifting focus from national ancestral histories to a more human-based understanding of the Viking Age. In this, a change in the historical narratives presented to the public is an important step in steering away from more toxic forms of nationalism.

\section{Conditions of Influence: What Enables the Scandinavian Populist Right to IMPACT Heritage Governance, And How Should Archaeologists Respond? Elisabeth Niklasson and Herdis Hølleland}

The 'politics of fear' (Wodak, 2015) exercised by radical and populist right-wing parties in Europe ought to concern archaeologists and heritage professionals for several reasons. The most immediate for us is these parties' enthusiasm for the distant past. Through symbolic manifestations, such as the Greek Golden Dawn's annual rally at the archaeological site of Thermopylae (Sotiris, 2015), the Italian Lega's use of Celtic imagery (Albertazzi, 2006), and the promotion by the French Front National (now rebranded as the Rassemblement National or National Rally) of medieval sites and festivals (Almeida, 2019), these parties claim ownership of heritage as a national concern. When these claims are translated into actual political proposals, negotiated and sometimes passed in parliaments, it revives an age-old dilemma: the heritage sectors in most of Europe are still closely linked to national governance, making them susceptible to political change. National heritage agencies usually report to central governments, and archaeological activities are regulated by state law and frequently funded by public funds. We are used to experiencing political change through budget cuts or structural reforms, but what happens when expectations of the past change? How are we to respond when democratically elected right-wing populist parties seek to reorient cultural politics to focus only on the ancient sites, monuments, and traditions they see as the essence of national identity? Where do we, as researchers and heritage professionals, set our limit of compliance? The scenario may seem hypothetical, but we do not have to look further than Hungary to see how it could play out, with new institutions distributing alternative narratives of the past (Bánffy, 2013). Drawing on our research into the uses of the past by the Scandinavian populist right wing (Niklasson \& Hølleland, 2018), we argue for a heightened preparedness in times of political polarization by means of cross-sectorial solidarity and partnership, as well as reflexivity and resistance. 
As a region which has long nurtured its image of equality, tolerance, and welfare, Scandinavia is perhaps not the first place that comes to mind when discussing right-wing populism. Yet, since the turn of the millennium, it has seen three antiimmigration parties claim space in the national parliaments: the Danish Peoples Party (DPP), the Progress Party in Norway (PP) and the Sweden Democrats (SD). When looking in detail at their respective cultural policies and proposals, we found that, for these parties, culture is almost synonymous with heritage (Niklasson \& Hølleland, 2018). The aim of their cultural policy is to strengthen a national identity by protecting and endorsing sites tied to notions of national origins and power, and to nurture rural folklife and the (Christian) traditions of the (ethno-national) majority population. To implement and fund their heritage policies, they seek to steer state funds away from multicultural initiatives and institutions working with contemporary art and world cultures. More than policy content, however, what makes their proposals dangerous is how these parties couch them in an already established rhetoric of heritage democratization. By taking a stand for the 'real' heritage of a nation and promising to bring it 'back to the people', they co-opt the Scandinavian model of state-subsidized culture-meant to ensure freedom of expression and equal access (e.g. Lindsköld, 2015)—to restrict ideas about what it means to belong in Scandinavian societies. While not immediately visible, this can have long-term effects; and, as archaeologists and heritage professionals, we need to generate a sense of preparedness. More than just reacting to the populist right's uses of the past, this requires identifying the political, bureaucratic, and societal conditions that enable right-wing populist tendencies to influence heritage governance in liberal democracies.
For Scandinavia, we identify three such conditions. The first is the destabilization of traditional block-politics in multiparty systems. With regard to heritage policy, our research has shown that the most influential position for a populist rightwing party in Scandinavia is that of support to right-wing minority (coalition) governments (Niklasson \& Hølleland, 2018). From this position, it can be contrary while still enjoying political legitimacy and getting some carefully chosen policies passed. In Denmark, the DPP has successfully made it its strategy to act as a support party for conservative minority coalitions since 2002. This has allowed it to influence heritage governance by increasing funding for its preferred sites, such as the Viking Age rune stones at Jelling, museums representing rural life, royal palaces, and navy ships. In this position, the DPP has managed to promote its policies in exchange for voting with the ruling block. More importantly, it did so without bearing the burden of responsibility or having to compromise as a governing party does. In Norway, the PP lost most of its radical edge once it was 'sanitized' and 'accepted' into a minority coalition in 2013, in a government that needed votes from other support parties (Bjerkem, 2016). The DPP's strategy has only been possible because the political establishment has welcomed it. SD, who is also in opposition, has not been so lucky. Due to instability, however, SD has held the role of 'scale master' in the Swedish parliament, able to tip the scales with its vote, but it still faces a cordon sanitaire, with no other parties willing to cooperate on a more permanent basis.

Stretching beyond the multiparty system, the second condition is the relocation of the so-called 'Overton window' (named after the American policy analyst Joseph Overton, referring to an idea's political viability depending on its 
acceptability) (Lehman, 2010). In other words, populist right-wing parties, by constantly proposing shocking measures, can reframe a society's window of ideational and rhetorical acceptance so that policies once seen as radical become normalized. In Scandinavia, the populist right has successfully shifted the window on their core issue of immigration to the point where other establishment parties have either budged or introduced similar policies. Rather than viewing heritage on its own, we therefore need to understand how it operates in relation to immigration policies. While presented as a heart-warming, political goodwill area when discussed by itself, heritage still serves as an instrument of division. In claiming to represent and safeguard the cultural values and material remains of 'the people', the populist right's arguments for heritage preservation help shift the window towards intolerance when used as a backdrop and contrast to contemporary immigration. In the visual language of the parties, the former is represented as appealing, with idealized images of what the future may hold with them in power, including blond children playing in the countryside and sunsets over ancient monuments, while the latter promises car fires and invasion if today's governments are left to define the future.

Third, gaps left by changes in governance should be addressed. In particular, we need to carefully consider the consequences of the trend to devolve authority to regional and local levels in the name of democracy and efficiency. As the populist right aspire to shift power from the elite to 'the people', neo-liberal de-bureaucratization measures such as those recently introduced by the current coalition government in Norway (Hølleland \& Skrede, 2019) can lead to a strategic hollowingout of expertise. Even if the national heritage sector's call for democratization aligns with populist-right agendas on the surface, it can be a false move that eventually leads to increased political control of heritagea long-term policy of the PP. Thus, even if the PP is of the opinion that the state (rather than private owners) should carry the financial burden of preserving listed buildings and funding archaeological excavations, the decisions regarding what is to be preserved should lie with 'the people' in the form of those elected to local and county governments.

What does this mean for researchers, archaeologists, and civil servants? What should we do when these conditions align? Our call is for solidarity, partnership, reflexivity, and resistance.

By solidarity, we refer to the need to stand up not just for our own field, but also for other cultural fields. When the populist right suggests cutting funds for the arts and multicultural initiatives in favour of archaeology and heritage, it should concern us. By actively siding with those targeted, political goodwill and capital may be at risk, but moral authority - a cornerstone of liberal democratic institutions-is gained. Furthermore, the heritage sector may have a good ally once the tables turn.

By partnership, we refer to the relationship between heritage researchers and civil servants. While relatively independent, there are limits to what Scandinavian heritage institutions can do and what civil servants can say. Equally, there are limits to what heritage researchers can know about the inner workings of heritage institutions (e.g. Hølleland \& Niklasson, 2020). Strategic partnerships could improve knowledge about the contract between the nation-states and their heritage sectors and increase preparedness for political instability.

By reflexivity, we mean not losing sight of the historical legacy of archaeology, which has taught us that we cannot easily dissociate racism from the concept of culture (see also Furholt here). When considering the policies of the populist right, 
we must be aware that proposals to fund iconic heritage sites and proposals to step up border controls represent two edges of the same sword.

Finally, by resistance, we mean that we must establish limits of compliance, for ourselves and as a sector, and work to uphold those limits at every turn. Archaeology has a history of compliance, from serving colonial empires to oil companies. Where do we draw the line when it comes to the populist right? So far, the reception of the populist right's heritage policies by the heritage sectors in Scandinavia points towards a slippery slope. Responses have varied greatly in the three countries. Archaeologists and civil servants in Denmark have taken advantage of the DPP's rhetoric to boost funding for excavations of Viking Age sites and museums (Jensen, 2009). In Sweden, representatives of the national heritage board have rebuffed SD's talk of a 'pure' Swedish past, but when SD arranged a parliamentary meeting to secure funds for the Iron Age site of Uppåkra in 2018, they went along with the show. We believe it is time to have an open discussion about where we stand as a field and formulate archaeo-political strategies based on the conditions of political influence in different regions.

\section{ACKNOWLEDGEMENTS}

SSR gratefully acknowledges M.J. Walsh, J.-L. Renaud, and another anonymous colleague for comments on this manuscript. MB would like to thank P. Pavúk, N. Vlhová, and M. Havlíková for reading and commenting on his paper. KK gratefully acknowledges the editorial help of his friend Sappho Haralambous-Howe. Naturally, the views and opinions expressed here are those of the authors and do not reflect the official policy or position of other agencies.

\section{REFERENCES}

Albertazzi, D. 2006. 'Back to our Roots' or Self-Confessed Manipulation? The Uses of the Past in the Lega Nord's Positing of Padania. National Identities, 8: 21-39.

Allentoft, M.E., Sikora, M., Sjögren, K.-G., Rasmussen, S., Rasmussen, M., Stenderup, J., et al. 2015. Population Genomics of Bronze Age Eurasia. Nature, 522: 167-72.

Almeida, D. 2019. Cultural Retaliation: The Cultural Policies of the 'New' Front National. International Journal of Cultural Policy, 25: 269-81.

Anderson-Whymark, H. \& Garrow, D. 2015. Seaways and Shared Ways: Imagining and Imaging the Movement of People, Objects and Ideas over the Course of the Mesolithic-Neolithic Transition, c. 50003500 BC. In: H. Anderson-Whymark, D. Garrow \& F. Sturt, eds. Continental Connections: Exploring Cross-Channel Relationships from the Mesolithic to the Iron Age. Oxford: Oxbow, pp. 59-77.

Appadurai, A. 1996. Modernity at Large: Cultural Dimensions of Globalisation. Minneapolis (MN): University of Minnesota Press.

Appiah, K.A. 2018. The Lies that Bind: Rethinking Identity. London: Profile Books.

Arendt, H. 1963. Eichmann in Jerusalem: A Report on the Banality of Evil. New York: Viking Press.

Arnold, B. 1990. The Past as Propaganda: Totalitarian Archaeology in Nazi Germany. Antiquity, 64: 464-78.

Aslanidis, P. 2016. Is Populism an Ideology? A Refutation and a New Perspective. Political Studies, 64 (suppl. 1): 88-104.

Babić, S., Karl, R., Milosavljević, M., Mizoguchi, K., Paludan-Müller, C., Murray, T., et al. 2017. What is 'European Archaeology'? What Should it Be? European Journal of Archaeology, 20: 4-35.

Bánffy, E. 2013. Disarmed Post-socialist Archaeologies? Social Attitudes to Interpreting the Past: An Interim Report from Hungary. In: E. Niklasson \& T. Meier, eds. Appropriate Narratives: Archaeologists, Publics and Stories. Budapest: Archaeolingua, pp. 271-94.

Bánffy, E., Bayliss, A., Denaire, A., Gaydarska, B., Hofmann, D., Lefranc, P., et al. 2018. Seeking the Holy Grail: Robust Chronologies from Archaeology 
and Radiocarbon Dating Combined. Documenta Praehistorica, 45: 120-37.

Barley, N. 1983. The Innocent Anthropologist: Notes from a Mud Hut. Long Grove (IL): Waveland Press.

Barras, C. 2019. Story of Most Murderous People of all Time Revealed in Ancient DNA. New Scientist [online]. [accessed April 2 2019]. Available at: https://www. newscientist.com/article/mg24132230-

200-story-of-most-murderous-people-ofall-time-revealed-in-ancient-dna/

Bennett, B. 2012. Encounters in the District Six Museum. Curator: The Museum Journal, 55: 319-25.

Bernbeck, R. \& Pollock, S. 2018. Archaeology's 'People'. Antiquity, 92: 516-17.

Binford, L. 1962. Archaeology as Anthropology. American Antiquity, 11: 198-200.

Bjerkem, J. 2016. The Norwegian Progress Party: An Established Populist Party. European View, 15: 233-43.

Boeri, T., Mishra, P., Papageorgiou, C. \& Spilimbergo, A. 2018. Populism and Civil Society (International Monetary Fund Working Paper 18/245) [online] [accessed 3 June 2021]. Available at: <https://www. imf.org/en/Publications/WP/Issues/2018/ 11/17/Populism-and-Civil-Society-46324>

Bonacchi, C., Altaweel, M. \& Krzyzanska, M. 2018. The Heritage of Brexit: Roles of the Past in the Construction of Political Identities through Social Media. Journal of Social Archaeology, 18: 174-92.

Bond, S.E. 2018. Vox Populi: Tips for Academics Transitioning to Public Scholarship. Forbes, 31 January 2018 [online] [accessed 3 June 2021]. Available at: https:// www.forbes.com/sites/drsarahbond/2018/01/ 31/vox-populi-tips-for-academics-transitioning-to-public-scholarship/?sh=46f366841a60

Børsheim, R.L. \& Soltvedt, E.-C. 2002. Gausel - utgravingene 1997-2000 (AmSVaria 39). Stavanger: Museum of Archaeology, University of Stavanger.

Bottici, C. 2008. Europe, War and Remembrance. In: F. Cerutti \& S. Lucarellil, eds. The Search for a European Identity: Values, Polices and Legitimacy of the European Union. London \& New York: Routledge, pp. 45-58.

Brather, S. 2008. Virchow and Kossinna: From the Science-Based Anthropology of Humankind to the Culture-Historical Archaeology of Peoples. In: N. Schlanger
\& J. Nordbladh, eds. Archives, Ancestors, Practices: Archaeology in the Light of its History. New York: Berghahn Books, pp. 317-34.

Brophy, K. 2018. The Brexit Hypothesis and Prehistory. Antiquity, 92: 1650-58.

Brophy, K. 2019. The Moggalithic Antiquarian: Party Political Broadcasts from Stone Circles. Almost Archaeology Blog [online] [accessed 26 January 2020]. Available at: https://almostarchaeology.com/post/ 189644783963/moggalithic

Brück, J. \& Stutz, L.N. 2016. Is Archaeology still the Project of Nation States? An Editorial Comment. Archaeological Dialogues, 23 (1): 1-3.

Cannadine, D. 2013. The Undivided Past: History Beyond our Differences. London: Penguin.

Childe, V.G. 1933. Is Prehistory Practical? Antiquity, 7: 410-18.

Chowne, P., Kotsakis, K. \& Orbasli, A. 2007. Management Plan for Prehistoric Sites. In: I. Hodder \& D. Louise, eds. Mediterranean Prehistoric Heritage: Training, Education and Management. Cambridge: McDonald Institute for Archaeological Research, pp. 9-20.

Cinpoeş, R. 2010. Nationalism and Identity in Romania: A History of Extreme Politics from the Birth of the State to EU Accession. London: Tauris Academic Studies.

Čížik, T. \& Masariková, M. 2018: Cultural Identity as Tool of Russian Information Warfare: Examples from Slovakia. Science and Military, 1/2018: 11-16.

Clarke, D. 1968. Analytical Archaeology. London: Methuen.

Conkey, M. 2002. Has Feminism Changed Archaeology? Signs: Journal of Women and Culture in Society, 28: 867-80.

Cox, M. 2017. The Rise of Populism and the Crisis of Globalisation: Brexit, Trump and Beyond. Irish Studies in International Affairs, 28: 9-17.

Damaskos, D. \& Plantzos, D. eds. 2008. A Singular Antiquity. Archaeology and Hellenic Antiquity in Twentieth-Century Greece. Athens: Mouseio Benaki.

De Cleen, B. \& Stavrakakis, Y. 2017. Distinctions and Articulations: A Discourse Theoretical Framework for the Study of Populism and Nationalism. Javnost - The Public, 24: 301-19.

D’Oriano, R. 2014. Le statue di Mont'e Prama e il fantarcheosardismo. In: L. 
Usai, ed. Le sculture di Mont' e Prama Catalogo della mostra (Li Punti, Sassari 2011). Roma: Centro di Conservazione Archeologica, pp. 193-202.

Eggert, M.K.H. 1978. Zum Kulturkonzept in der prähistorischen Archäologie. Bonner Jahrbücher, 178: 1-20.

Eisenmann, S., Bánffy, E., Van Dommelen, P., Hofmann, K.P., Maran, J., Lazaridis, I., et al. 2018. Reconciling Material Cultures in Archaeology with Genetic Data: The Nomenclature of Clusters Emerging from Archaeogenomic Research. Scientific Reports, 8: 13003. https://doi.org/10.1038/ s41598-018-31123-z

Evin, F. 2015. Was Sardinia Home to the Mythical Civilisation of Atlantis? The Guardian, 15.08.2015 [online] [accessed 3 June 2021]. Available at: https://www. theguardian.com/science/2015/aug/15/

bronze-age-sardinia-archaeology-atlantis

Fidjestøl, B. 1993. Skaldekvada og Harald Hårfagre. In: M.S. Vea \& B. Myhre, eds. Riksamlingen og Harald Hårfagre. Historisk seminar på karmøy 10-11. Juni 1993. Karmøy: Karmøy commune, pp. 7-31.

Frau, S. 2002. Le colonne d'Ercole: un'inchiesta. Roma: Nur Neon.

Frei, K.M. 2018. Egtvedpigens Rejse. København: Lindhardt \& Ringhof.

Frieman, C.J. \& Hofmann, D. 2019. Present Pasts in the Archaeology of Genetics, Identity, and Migration in Europe: A Critical Essay. World Archaeology, 51: 52845. https://doi.org/10.1080/00438243. 2019.1627907

Frieman, C.J. \& Wilkin, N. 2016. 'The Changing of the Guards'? British Prehistoric Collections and Archaeology in the Museums of the Future. Museum World: Advances in Research, 4: 33-50.

Furholt, M. 2009. Die nördlichen Badener Keramikstile im Kontext des mitteleuropäischen Spätneolithikums (3650-2900 v. Chr.). Bonn: Habelt.

Furholt, M. 2018. Massive Migrations? The Impact of Recent aDNA Studies on our View of Third Millennium Europe. European Journal of Archaeology, 21: 15991.

Furholt, M. 2019a. De-Contaminating the aDNA-Archaeology Dialogue on Mobility and Migration: Discussing the CultureHistorical Legacy. Current Swedish Archaeology, 27: 11-26.
Furholt, M. 2019b. Re-Integrating Archaeology: A Contribution to aDNA Studies and the Migration Discourse on the 3rd Millennium BC in Europe. Proceedings of the Prehistoric Society, 85: 115-29. https://doi.org/10.1017/ppr.2019.4

Furholt, M. 2021. Mobility and Social Change: Understanding the European Neolithic Period After the Archaeogenetic Revolution. Journal of Archaeological Research https://doi. org/10.1007/s10814-020-09153-x

Galli, E, \& Garzarelli, G. 2019. Populism as Composite Ideology. Turkish Policy Quarterly, 18: 93-99.

Gardner, A. 2018. Power, Knowledge and the Past. Antiquity, 92: 1662-64.

Globsec. 2018. Globsec Trends 2018. Central Europe: One Region, Different Perspectives [online] [accessed 3 June 2021]. Available at: https://www.globsec.org/wp-content/uploads/ 2018/05/GLOBSEC-Trends-2018.pdf.

Bratislava: Globsec Policy Institute.

Golder, M. 2016. Far Right Parties in Europe. Annual Review of Political Science, 19: 477-97.

González-Ruibal, A. 2014. Archaeological Revolution(s). Current Swedish Archaeology, 22: 41-45.

González-Ruibal, A. 2018a. Welcome Conflict: Archaeology and the Return of the Political. Keynote lecture presented at the European Archaeological Association annual meeting, Barcelona, Spain, 6 September 2018.

González-Ruibal, A. 2018b. An Archaeology of the Contemporary Era. Abingdon \& New York: Routledge.

González-Ruibal, A., González, P.A. \& Criado-Boado, F. 2018. Against Reactionary Populism: Towards a New Public Archaeology. Antiquity, 92: 507-15.

Gramsch, A. 2011. Theory in Central European Archaeology: Dead or Alive? In: J. Bintliff \& M. Pearce, eds. The Death of Archaeological Theory? Oxford: Oxbow Books, pp. 48-71.

Grøsfjeld, S. 2018. Historikermiljøet er sterkt involvert i Vikingtiden. Stavanger Aftenblad, 7 December, p. 37.

Grosfoguel, R. 2011. Decolonizing PostColonial Studies and Paradigms of Political Economy: Transmodernity, Decolonial Thinking, and Global Coloniality. TRANSMODERNIT, Journal of Peripheral 
Cultural Production of the Luso-Hispanic World, 1. https://escholarship.org/uc/item/ $21 \mathrm{k} 6 \mathrm{t} 3 \mathrm{fq}$

Haak, W., Lazaridis, I., Patterson, N., Rohland, N., Mallick, S., Llamas, B., et al. 2015. Massive Migration from the Steppe was a Source for Indo-European Languages in Europe. Nature, 522: 207-11.

Habermas, J. 2001. The Postnational Constellation (trans. M. Pensky). Cambridge (MA): MIT Press.

Halpin, M. 1997. 'Play it Again, Sam': Reflections on a New Museology. Museum International, 49: 52-56.

Halstead, P. 2014. Two Oxen Ahead: PreMechanised Farming in the Mediterranean. Oxford: Wiley Blackwell.

Hamilakis, Y. 2018. Decolonial Archaeology as Social Justice. Antiquity, 92: 518-20.

Hamilakis, Y. \& Yalouri, E. 1996. Antiquities as Symbolic Capital in Modern Greek Society. Antiquity, 70: 117-29.

Hanscam, E. 2019. Postnationalism and the Past: The Politics of Theory in Roman Archaeology. Theoretical Roman Archaeology Journal, 2: 3.

Harari, Y.N. 2015. Sapience: A Brief History of Humankind. London: Vintage.

Härke, H. 1995. 'The Hun is a Methodical Chap': Reflections on the German Tradition of Pre- and Proto-History. In: P.J. Ucko, ed. Theory in Archaeology: $A$ World Perspective. London \& New York: Routledge, pp. 46-60.

Hingley, R., Bonacchi, C. \& Sharpe, K. 2018. 'Are You Local?' Indigenous Iron Age and Mobile Roman and Post-Roman Populations: Then, Now, and In-Between. Britannia, 49: 1-20.

Hobsbawm, E.J. 1992. Ethnicity and Nationalism in Europe Today. Anthropology Today, 8: 3-8.

Hodder, I. 1982. Symbols in Action: Ethnoarchaeological Studies of Material Culture. Cambridge: Cambridge University Press.

Hodder, I. 1999. The Archaeological Process: An Introduction. Oxford: Blackwell.

Hoffos, S. 1992. Multimedia and the Interactive Display in Museums, Exbibitions and Libraries (Library and Information Research Report 87). London: British Library.

Hølleland, H. \& Niklasson, E. 2020. How (Not) To 'Study Up': Points and Pitfalls When Studying International Heritage
Regimes. Journal of Field Archaeology, 45: 140-52. https://doi.org/10.1080/00934690. 2019.1709782

Hølleland, H. \& Skrede, J. 2019. Regionreformen: Demokratisering og politisering av kulturminneforvaltningen. Heimen, 56: 127-42. https://doi.org/10. 18261/issn.1894-3195-2019-02-05

Holtorf, C. 2007. Archaeology is a Brand! The Meaning of Archaeology in Contemporary Popular Culture. Oxford: Archaeopress.

Holtorf, C. \& Högberg, A. 2015. Contemporary Heritage and the Future. In: E. Waterton \& S. Watson, eds. The Palgrave Handbook of Contemporary Heritage Research. New York: Palgrave Mcmillan, pp. 509-23.

Holtorf, C., Pantazatos, A. \& Scarre, G. eds. 2019. Cultural Heritage, Ethics and Contemporary Migrations. London: Routledge.

Ivanovaite, L., Serwatka, K., Hoggard, C.S., Sauer, F. \& Riede, F. 2020. All These Fantastic Cultures? Research History and Regionalization in the Late Palaeolithic Tanged Point Cultures of Eastern Europe. European Journal of Archaeology, 23: 16285.

Jakucs, J., Bánffy, E., Oross, K., Voicsek, V., Bronk Ramsey, C., Dunbar, E., et al. 2016. Between the Vinča and Linearbandkeramik Worlds: The Diversity of Practices and Identities in the 54th53rd Centuries cal BC in Southwest Hungary and Beyond. Journal of World Prehistory, 29: 267-336.

Jensen, M.B. 2009. Kulturarven og myten om den historiske identitet. En diskursanalyse af arkæologiens rolle $\mathrm{i}$ det senmoderne samfund (unpublished $\mathrm{PhD}$ dissrtation, Aarhus University).

Johnson, M. 2015. Lives in Ruins: Archaeology and the Seductive Lure of Human Rubble. New York: Harper Perennial.

Johnston, B. 2002. Italian Stonehenge Found on Mountain. The Telegraph online, 22.10.2002 [online] [accessed 3 June 2021]. Available at: <https://www.telegraph.co.uk/news/worldnews/europe/italy/ 1410960/Italian-Stonehenge-found-onmountain.html>

Kajda, K., Marx, A., Wright, H., Richards, J., Marciniak, A., Rossenbach, K.S., et al. 2018. Archaeology, Heritage, and Social Value: Public Perspectives on European 
Archaeology. European Journal of Archaeology, 21: 96-117.

Kalela, J. 2012. Making History: The Historian Uses of the Past. New York: Palgrave Macmillan.

Kiddey, R. 2017. Homeless Heritage: Collaborative Social Archaeology as Therapeutic Practice. Oxford: Oxford University Press.

Kiddey, R. 2020. I'll Tell You What I Want, What I Really, Really Want! Open Archaeology that is Collaborative, Participatory, Public, and Feminist. Norwegian Archaeological Review, 53: 23-40.

Kohler, T.A. \& Rockman, M. 2020. The IPCC: A Primer for Archaeologists. American Antiquity, 85: 627-51.

Kossinna, G. 1911. Die Herkunft der Germanen. Zur Methode der Siedlungsarchäologie. Würzburg: Kabitzsch.

Kossinna, G. 1912. Die deutsche Vorgeschichte, eine hervorragende nationale Wissenschaft. Würzburg: Kabitzsch.

Kotsakis, K. 1991. The Powerful Past: Theoretical Trends in Greek Archaeology. In: I. Hodder, ed. Archaeological Theory in Europe. London: Routledge, pp. 65-90.

Kotsakis, K. 1998. The Past is Ours: Images of Greek Macedonia. In: L. Meskell, ed. Archaeology Under Fire. London: Routledge, pp. 44-67.

Krause, J. \& Trappe, T. 2019. Die Reise unserer Gene. Eine Geschichte über uns und unsere Vorfahren. Berlin: Propyläen.

Krekovič, E. 2007. Who Was First? Nationalism in Slovak and Hungarian Archaeology and History. Archaeologies: Journal of the World Archaeological Congress, 3: 59-67.

Krekovič, E. \& Bača, M. 2014. Marxism, Communism and Czechoslovak Archaeology. Anthropologie, 51: 261-70.

Kristiansen, K. 1993. 'The Strength of the Past and its Great Might': An Essay on the Use of the Past. Journal of European Archaeology, 1: 3-32.

Kristiansen, K. 2008. Do We Need the 'Archaeology of Europe'? Archaeological Dialogues, 15: 5-25.

Kristiansen, K., Allentoft, M.E., Frei, K.M., Iversen, R., Johannsen, N.N., Kroonen, G., et al. 2017. Re-theorising Mobility and the Formation of Culture and Language among the Corded Ware Culture in Europe. Antiquity, 91: 334-47.
Kundera, M. 1984. The Tragedy of Central Europe. New York Review of Books, 31: 33-38.

Laclau, E. 2005. On Populist Reason. London: Verso.

Lehman, J.G. 2010. An Introduction to the Overton Window of Political Possibility. Mackinac Center for Public Policy [online] [accessed 3 June 2021]. Available at: <https://www.mackinac.org/12481>

Lilliu, G. 2002 (1971). La costante resistenziale sarda. Milano: Ilisso.

Lindsköld, L. 2015. Contradicting Cultural Policy: A Comparative Study of the Cultural Policy of the Scandinavian Radical Right. Nordisk kulturpolitisk tidskrift/ The Nordic Journal of Cultural Policy, 18: 8-27.

Lüning, J. 1972. Zum Kulturbegriff im Neolithikum. Praebistorische Zeitschrift, 47: 145-73.

Lüning, J. 1979. Über den Stand der neolithischen Stilfrage in Südwestdeutschland. Jahrbuch des Römisch-Germanischen Zentralmuseums Mainz, 26: 75-113.

Madsen, O. 2018. Faglig håndtering av vikingtiden. Stavanger Aftenblad, 21 December, p. 31.

Maples, W.R. \& Browning, M. 1994. Dead Men Do Tell Tales: The Strange and Fascinating Cases of a Forensic Anthropologist. London: Souvenir Press.

Marx, A., Nurra, F. \& Salas Rossenbach, K., eds. 2017. Europeans and Archaeology: $A$ Survey on the European Perception of Archaeology and Archaeological Heritage. Paris: NEARCH.

Mason, P. 2019. Clear Bright Future: $A$ Radical Defence of the Human Being. London: Penguin.

Meller, H. \& Michel, K. 2018. Die Himmelsscheibe von Nebra: Der Schlüssel zu einer untergegangenen Kultur im Herzen Europas. Berlin: Propyläen.

Milek, K. 2018. Transdisciplinary Archaeology and the Future of Archaeological Practice: Citizen Science, Portable Science, Ethical Science. Norwegian Archaeological Review, 51: 38-47.

Moshenska, G. \& Zuanni, C. 2018. Public Archaeology. In: S.L. López Varela, ed. The Encyclopedia of Archaeological Sciences. Oxford: Wiley Blackwell. https:// doi.org/10.1002/9781119188230.saseas0480 
Mudde, C. 2004. The Populist Zeitgeist. Government and Opposition, 39: 541-63.

Müller, J. 2001. Soziochronologische Studien zum Jung- und Spätneolithikum im MittelelbeSaale-Gebiet (4100-2700 v. Chr.). Rahden: Marie Leidorf.

Müller, J.-W. 2016. What is Populism. Philadelphia (PA): University of Pennsylvania Press.

Niklasson, E. \& Hølleland, H. 2018. The Scandinavian Far-Right and the New Politicisation of Heritage. Journal of Social Archaeology, 18: 121-48.

Nilsson Stutz, L. 2018. A Future for Archaeology: In Defense of an Intellectually Engaged, Collaborative and Confident Archaeology. Norwegian Archaeological Review, 51: 48-56.

Olalde, I., Brace, S., Allentoft, M.E., Armit, I., Kristiansen, K., Booth, T., et al. 2018. The Beaker Phenomenon and the Genomic Transformation of Northwest Europe. Nature, 555: 190-96.

Olalde, I., Mallick, S., Patterson, N., Rohland, N., Villalba-Mouco, V., Silva, M., et al. 2019. The Genomic History of the Iberian Peninsula over the Past 8000 Years. Science, 363: 1230-34.

Özkirimli, U. 2005. Contemporary Debates on Nationalism. Basingstoke: Palgrave Macmillan.

Pálsson, G. 2007. Anthropology and the New Genetics. Cambridge: Cambridge University Press.

Panich, L. \& Schneider, T. 2019. Categorical Denial: Evaluating Post-1492 Indigenous Erasure in the Paper Trail of American Archaeology. American Antiquity, 84: 65168.

Parlani, X. 2014. Ethnographic Research at Paliambela Kolindrou in Relation to the Archaeological Excavation Project. Unpublished report [in Greek], Paliambela Excavation Archive. Thessaloniki: University of Thessaloniki.

Pentz, P., Varberg, J. \& Sørensen, L. 2019. Meet the Vikings: For Real! Antiquity, 93: 1-5.

Perry, S. 2019. The Enchantment of the Archaeological Record. European Journal of Archaeology, 22: 354-71.

Popa, C.N. 2015. Late Iron Age Archaeology in Romania and the Politics of the Past. Dacia N.S., 59: 337-61.
Popa, C.N. 2019. The Responsibility of European Archaeologists. European Journal of Archaeology, 22: 255-68.

Popa, C.N. \& Hanscam, E. 2019-2020. Of Romans, Dacians and Romanians. ARCHAICA, 7: 243-51.

Prentiss, A.M. 2012. Field Seasons: Reflections of Career Paths and Research in American Archaeology. Salt Lake City (UT): University of Utah Press.

Pulselli, F.M., Sani, A., Goffetti, G., Coscieme, L. \& Bastianoni, S. 2019. A Sustainability 3D Framework of the 20 Regions of Italy and Comparison with World Countries. Frontiers in Energy Research, 7: 82.

Recabarren, M., Nussbaum, M. \& Leiva, C. 2007. Cultural Illiteracy and the Internet. Cyber Psychology and Behaviour, 10: 85356.

Reich, D. 2018. Who We Are and How We Got Here: Ancient DNA and the New Science of the Human Past. New York: Pantheon Books.

Risa, E. 2018. Stavanger og Rogaland må utnytte posisjonen som vikingfylke. Stavanger Aftenblad, 21 November, p. 12.

Risse, T. 2004. European Institutions and Identity Change: What Have we Learned? In: R. Herrmann, T. Risse \& M.B. Brewer, eds. Transnational Identities: Becoming European in the EU. Lanham (MD): Rowman \& Littlefield, pp. 24771.

Roberts, B.W. \& Vander Linden, M. eds. 2011. Investigating Archaeological Cultures Material Culture, Variability, and Transmission. New York: Springer.

Rowlands, M. 1994. The Politics of Identity in Archaeology. In: G.C. Bond \& A. Gilliam, eds. Social Construction of the Past. London \& New York: Routledge, pp. 129-43.

Rybár, L. 2020. Islam v slovenských učebniciach dejepisu. Historický časopis, 68: 137-52.

Schlanger, N. 2018. The Brexit Syndrome: Towards a Hostile Historic Environment? Antiquity, 92: 1665-68.

Schwarzkopf, S. 2011. The Consumer as 'Voter', 'Judge', and 'Jury': Historical Origins and Political Consequences of a Marketing Myth. Journal of Macromarketing, 31: 8-18. 
Shanks, M. \& Tilley, C. 1987. Social Theory and Archaeology. Albuquerque (NM): University of New Mexico Press.

Shennan, S. 1989. Introduction: Archaeological Approaches to Cultural Identity. In: S. Shennan, ed. Archaeological Approaches to Cultural Identity. London: Unwin Hyman, pp. 1-32.

Smith, L. \& Campbell, G. 2018. It's Not All About Archaeology. Antiquity, 93: 52122.

Snyder, T. 2018. The Road to Unfreedom: Russia, Europe, America. New York: Tim Duggan Books.

Sommer, U. 2011. Tribes, Peoples, Ethnicity: Archaeology and Changing 'We Groups'. In: E. Cochrane \& A. Gardner, eds. Evolutionary and Interpretive Archaeologies: $A$ Dialogue. Walnut Creek (CA): Left Coast Press, pp. 169-98.

Sotiris, P. 2015. Political Crisis and the Rise of the Far Right in Greece: Racism, Nationalism, Authoritarianism and Conservatism in the Discourse of Golden Dawn. Journal of Language Aggression and Conflict, 3: 173-99.

Stanley, B. 2008. The Thin Ideology of Populism. Journal of Political Ideologies, 13: 95-110.

Stavrakakis, Y. 2017. Populism and Hegemony. In: C. R. Kaltwasser, P. Taggart, P. Ochoa Espejo \& P. Ostiguy, eds. The Oxford Handbook of Populism. Oxford: Oxford University Press, pp. 535-53.

Steenvoorden, E. \& Harteveld, E. 2017. The Appeal of Nostalgia: The Influence of Societal Pessimism on Support for Populist Radical Right Parties. West European Politics, 41: 28-52.

Strien, H.-C. 2017. Discrepancies Between Archaeological and 14C-Based Chronologies: Problems and Possible Solutions. Documenta Praebistorica, 44: 272-80.

Strien, H.-C. 2019. 'Robust Chronologies' or 'Bayesian Illusion'? Some Critical Remarks on the Use of Chronological Modelling. Documenta Praehistorica, 46: 204-15.

Sutherland, C. 2012. Nationalism in the Twenty-First Century: Challenges and Responses. New York: Palgrave Macmillan.

Synnestvedt, A. 2009. Archaeology as a Meeting Point for Multicultural Regeneration [online] [accessed 3 June 2021]. Unpublished report available at: <https://www.academia.edu/ 5560362/Archaeology_as_a_meeting_point_ for_multicultural_regeneration.>
Taggart, P. \& Kaltwasser, C.R. 2016. Dealing with Populists in Government: Some Comparative Conclusions. Democratization, 23: 345-65.

The Craftsman Initiative 2019. The Future is Handmade [online] [accessed 17 January 2020]. Available at: <https://youtu.be/ jOMujtoicTk>

Thomas, S. 2015. Collaborate, Condemn, or Ignore? Responding to NonArchaeological Approaches to Archaeological Heritage. European Journal of Archaeology, 18: 312-35.

Thornton, A. 2018. Archaeologists in Print: Publishing for the People. London: UCL Press.

Titlestad, T. 2011. Forskarne og sagaene - og hva sagaene forteller om slaget $i$ Hafrsfjord. In: M. Nitter, ed. Tverrfaglige perspektiver 2 (AmS-Varia 53). Stavanger: Museum of Archaeology, University of Stavanger, pp. 15-22.

Titlestad, T. 2018. Vikingtiden og slaget i Hafrsfjord - uten betydning for Norge? Stavanger Aftenblad, 4 December [online] [accessed 8 June 2020]. Available at: https://www.aftenbladet.no/meninger/ debatt $/ \mathrm{i} / 2172 \mathrm{Ga} /$ vikingtiden-og-slaget-ihafrsfjord-uten-betydning-for-norge

Trigger, B. 1984. Alternative Archaeologies: Nationalist, Colonialist, Imperialist. Man, 19: 355-70.

Trigger, B. 1989. A History of Archaeological Thought. Cambridge: Cambridge University Press. 2nd edition 2006.

Tryfinopoulou, M. 2010. The Diachronic Relation of People with the Cultural Landscape. The Example of the Municipality of Kozani (unpublished MA Dissertation, The Aristotle University of Thessaloniki).

Tylor, E.B. 1871. Primitive Culture: Researches into the Development of Mythology, Philosophy, Religion, Language, Art, and Custom. London: John Murray.

Valera, A.C. \& Criado Boado, F. 2018. Genética de una "fake news": respuesta a las noticias sobre "invasiones" y "exterminios" en el III milenio antes de nuestra era en la Península Ibérica [online] [accessed 3 June 2021]. Las gafas de Childe, archaeology blog available at <https://lasgafasdechilde.es/ genetica-de-una-fake-news-respuesta-a-lasnoticias-sobre-invasiones-y-exterminios-enel-iii-milenio-antes-de-nuestra-era-en-lapeninsula-iberica/> 
Vander Linden, M. 2006. Le phénomène campaniforme dans l'Europe du 3ème millénaire avant notre ère: synthèse et nouvelles perspectives (BAR International Series 1470). Oxford: Archaeopress.

Vanzetti, A. in press. Nuragic Memories: A Deep-Seated Pervasive Attitude. In: S. Stoddart, ed. Gardening Time: Reflections on Memory, Monuments and History in Sardinia and Scotland. Cambridge: McDonald Institute of Archaeological Research.

Vasilev, G. 2019. Methodological Nationalism and the Politics of History-Writing: How Imaginary Scholarship Perpetuates the Nation. Nations and Nationalism, 25: 499522.

Veit, U. 1989. Ethnic Concepts in German Prehistory: A Case Study on the Relationship Between Cultural Identity and Archaeological Objectivity. In: S. Shennan, ed. Archaeological Approaches to Cultural Identity. London: Unwin Hyman, pp. 35-55.

Veit, U. 2002. From Nationalism to Nazism: Gustaf Kossinna and his Concept of a National Archaeology. In: H. Härke, ed. Archaeology, Ideology and Society: The German Experience. Frankfurt am Main: Peter Lang, pp. 40-64.

Velikonja, M. 2009. Lost in Transition: Nostalgia for Socialism in Post-Socialist Countries. East European Politics and Societies and Cultures, 23: 535-51.

Wahle, E. 1941. Zur ethnischen Deutung frühgeschichtlicher Kulturprovinzen. Grenzen der frühgeschichtlichen Erkenntnis. Heidelberg: Carl Winter.

Waterton, E. \& Smith, L. 2010. The Recognition and Misrecognition of
Community Heritage. International Journal of Heritage Studies, 16: 4-15.

Wiedemann, F. 2017. Zirkuläre Verknüpfungen. Völkerwanderungen und das Motiv der Wiederkehr in den Wissenschaften vom Alten Orient um 1900. In: F. Wiedemann, K. Hofmann \& H.-J. Gehrke, eds. Vom Wandern der Völker. Migrationserzäblungen in den Altertumswissenschaften. Berlin: Topoi, pp. 137-60.

Wilks, R.R. 1985. The Ancient Maya and the Political Present. Journal of Anthropological Research, 41: 307-26.

Willerslev, R. 2012. On the Run in Siberia. Minneapolis (MN): University of Minnesota.

Wimmer, A. \& Glick Schiller, N. 2003. Methodological Nationalism, the Social Sciences, and the Study of Migration: An Essay in Historical Epistemology. The International Migration Review, 37: 576-610.

Winter, T. \& Waterton, E. 2013. Critical Heritage Studies. International Journal of Heritage Studies, 19: 529-31.

Wodak, R. 2015. The Politics of Fear: What Right-Wing Populist Discourses Mean. London: Sage.

Wotzka, H.-P. 1993. Zum traditionellen Kulturbegriff in der prähistorischen Archäologie. Paideuma, 39: 25-44.

Wotzka, H.-P. 2000. "Kultur" in der deutschsprachigen Urgeschichtsforschung. In: S. Fröhlich, ed. Kultur - Ein interdisziplinäres Kolloquium zur Begrifflichkeit. Halle: Landesamt für Archäologie, pp. 55-80.

Zimmer, C. 2011. A Planet of Viruses. Chicago \& London: University of Chicago Press.

Zimmer, C. 2018. She Has her Mother's Laugh: The Story of Heredity, its Past, Present and Future. New York: Dutton. 